\title{
New data on the ecological peculiarities and the distribution in Bulgaria of the vulnerable habitat F3.1d Balkan- Anatolian submontane genistoid scrub from the European Red List of Habitats
}

\author{
Georgi Kunev $^{1}$ (i) \& Rossen Tzonev ${ }^{1}$
}

Key words: endemic vegetation, vulnerable habitat, Genista lydia complex, Balkan peninsula.

Ključne besede: endemična vegetacija, ogroženi habitati, kompleks Genista lydia, Balkanski polotok.

Received: 16. 10. 2018

Revision received: 28. 12. 2018

Accepted: 11. 1. 2019

\begin{abstract}
The study presents new data on the habitat dominated by the species complex of Genista lydia/G. rumelica in Bulgaria. It is based on 129 phytocoenological relevés and provides information on the chorology, ecology and floristic structure of these communities. This habitat type occupies substrates composed by different volcanic rocks. The floristic structure is very rich in species. The phytogeographical relationships with the East Mediterranean region are considerable, which is proved by the high occurrence of floristic elements with Mediterranean or sub-Mediterranean origin. The plant life-forms analysis demonstrates that the therophytes, geophytes and chamephytes prevail in their floristic structure, which is also typical for the shrub communities in this region. During the field study this vegetation type has been mapped and its total area of occupancy has been calculated. For a first time it is proposed this habitat to be divided into three habitat sub-types due to the established differences in the environmental factors. Some recommendations have been proposed on the conservation management and also complements on the habitat's descriptions in EUNIS habitat classification.
\end{abstract}

\section{Izvleček}

$\mathrm{V}$ članku predstavljamo nove podatke o habitatnih tipih, $\mathrm{v}$ katerih prevladuje kompleks vrst Genista lydia/G. rumelica v Bolgariji. Na osnovi 129 fitocenoloških popisov predstavljamo informacije o horologiji, ekologiji in floristični sestavi teh združb. Habitatni tip najdemo na matični podlagi, ki jo sestavljajo različne vulkanske kamnine. Floristična sestava je vrstno bogata. Povezava z vzhodno mediteransko regijo je očitna, kar dokazuje velik delež vrst mediteranskega in submediteranskega flornega elementa. Analiza življenskih oblik je pokazala, da $\mathrm{v}$ floristični sestavi prevladujejo terofiti, geofiti in hamefiti, kar je značilno za grmiščne združbe tega območja. Ta vegetacijski tip smo kartirali na terenu in izračunali skupno območje razširjenosti. Na osnovi ugotovljenih razlik v okoljskih dejavnikih predlagamo razdelitev habitatnega tipa v tri podtipe. Predlagamo tudi nekatere ukrepe za naravovarstveno gospodarjenje in dopolnitve k opisom habitatnega tipa v EUNIS habitatni klasifikaciji. 


\section{Introduction}

The communities dominated by the species complex of Genista lydia Boiss/G. rumelica Velen. have been a subject of continuous scientific interest due to the indigenous origin of the one of the dominant species and their restricted geographical range. However, there is no sufficient information in the scientific literature about their floristic structure, ecological features and distribution. Despite that both taxa are broadly accepted as synonyms, there are still opposing opinions considering the variability within this group of species still not fully known.

Genista lydia was published as new species by Boissier (1843) based on materials collected for Flora Orientalis from the hillsides of Bozdağ Mt. (Turkey). The range of this species is known to include the Balkan Peninsula, parts of Turkey and Syria (ILDIS World Database of Legumes 2010). An alternative taxonomic scheme for $G$. lydia was proposed by Zieliński et al. (2004), treating it as the easternmost subspecies of $G$. januensis Viv. The authors considers $G$. rumelica as an extreme morphotype of $G$. januensis ssp. lydia (Boiss.) Kit Tan \& Zieliński.

Genista rumelica was described for a first time by the Czech botanist Josef Velenovský during his work for Flora Bulgarica (see Velenovský 1890), on the basis of herbarium materials collected at Džendem Tepe locality (locus classicus), Plovdiv town, Bulgaria. Since then many authors have proposed different conceptions about the taxonomic position of this taxon. However, most of them have placed it in the G. lydia s. l., or accept it as only synonym (Turril 1957, Gibbs 1968, Ponert 1973, ILDIS World Database of Legumes 2010). For the Flora of P.R. Bulgaria, Kuzmanov (1976) have accepted G. rumeli$c a$ as a different species. Stoyanov (2014) distinguished G. lydia from $G$. rumellica by differences in their morphology, physical appearance and habitat's preferences. The research of Evstatieva et al. (2004), based on a chaemotaxonomical study of the genus Genista in Bulgaria, have concluded that $G$. rumelica distinctly differs from $G$. lydia by its alkaloid composition and both taxa should not be referred to one species. Therefore, these studies have confirmed $G$. rumelica as an endemic taxon for the territory of Bulgaria and Northern Greece, which conception was already accepted by Kuzmanov (1976).

Morphologically, both taxa are low 30-70 (100) cm shrubs (heaths), with procumbent to erect branches, whose leaves fall soon after the flowering period (Figure 1).

Their communities were firstly mentioned by Vasilev (1983) as a part of the Bulgarian endemic vegetation. After that, Velčev \& Bondev (1984a) have reported those

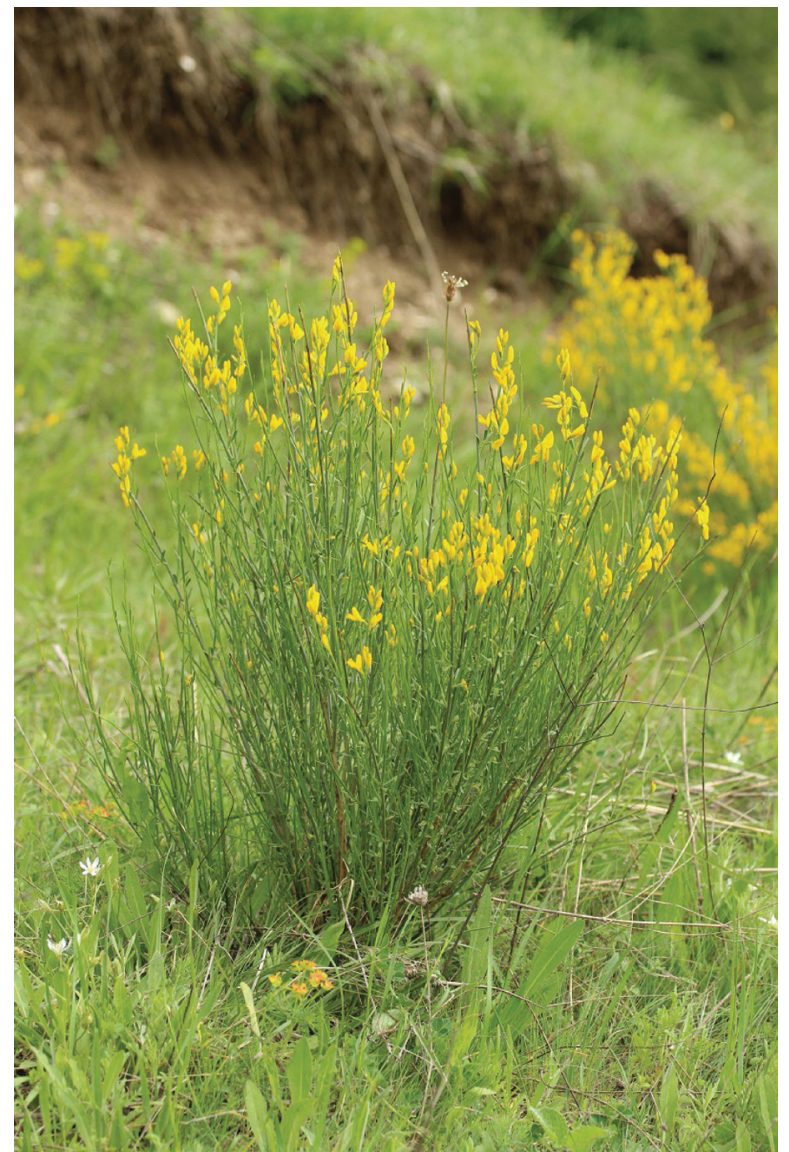

Figure 1: Genista rumelica in the natural habitat - Western Rhodope Mts. Slika 1: Genista rumelica na naravnem rastišču - zahodni Rodopi.

heathlands as an important part of the Bulgarian vegetation. They have also defined these communities as endangered due to their restricted distribution and have noted that this vegetation is maintained mainly as pastures. The same authors have reported 5 associations (determined using criteria of Russian-Scandinavian school) dominated by $G$. rumelica, and provided also information on their distribution. However, the collected field materials from their study have never been published (see Velčev \& Bondev 1984b). Additional data on the distribution of the studied communities in Bulgaria has been presented by Bondev (1991) in the map of vegetation (1:600 000) with an explanatory text. Also brief descriptions of their phytocoenoses have been given and some of co-dominants have been mentioned. Such species are Stipa capillata, Melica ciliata, Diplachne serotina, Dichantium ischaemum, Koeleria spp., Poa bulbosa and Satureja montana. Bondev has entitled this vegetation type as "124 Shrubs of Rumelian green weed (Genisteta rumelicae) (r) and of Lydian green weed (Genisteta lydiae) (l)". 
The most comprehensive study concerning on these communities was published by Tzonev \& Gussev (2015) in the Red Data Book of Bulgaria (vol. 3). In this book they have been entitled under the name " $21 \mathrm{~F} 3$ Mediterranean fields of Rumelian green weed (Genista rumelica) and Lydian green weed (Genista lydia)". The authors have described the habitat as a complex of shrub, herbaceous and chasmophytic plant species, occupying areas with shallow soils or bare rocks. The floristic composition is qualified as diverse and with many annuals and species of southern origin with limited distribution in Bulgaria. The relict and endemic origin on one of the dominant species, but also some other species from the floristic structure of the habitat, determined the conservation significance and threatened status of the studied communities. Data on their distribution in Bulgaria, ecological preferences and characteristic species as well as some conservation measures are also pointed in this entry.

The European Red List of Habitats (Janssen et al. 2016) was released as a first attempt to assess the current status of all terrestrial, freshwater and marine habitats in the continent and surrounding offshore areas. The communities of Genista lydia complex were aslo assessed under the name"F3.1d Balkan-Anatolian submontane genistoid scrub". According to the Red List criteria, the status of this habitat type is Vulnerable (see Janssen et al. 2016). The main reasons are the ongoing minor negative trends in its quality and quantity and the limited range of distribution, restricted to the southeast part of the Balkan Peninsula and West Anatolia. Information on the geographic occurrence, threats and restoration potential as well as the relationships with different classification systems have been also summarized in this survey. According to the available data, the current area of the habitat on the territory of Bulgaria is assumed to be about $60 \mathrm{~km}^{2}$, area of occupancy (AOO) - $32\left(3200 \mathrm{~km}^{2}\right)$, extent of occurrence (EOO) but for Bulgaria and Greece $-56000 \mathrm{~km}^{2}$ (Janssen et al. 2016).

EUNIS habitat classification (version 2017), revised for the forest, heathland, scrub and tundra vegetation (https://www.eea.europa.eu/data-and-maps/data/eunishabitat-classification) adopted the same habitat name from the European Red List of Habitats - S3-4. "BalkanAnatolian submontane genistoid scrub" and list of some diagnostic and characteristic species has also been provided. It includes Genista lydia, Minuartia hirsuta, Allium guttatum, Centaurea grisebachii, Hypericum olympicum, Thymus sibthorpii, Koeleria lobata, Micropyrum tenellum, Asperula aristata and Rumex acetosella.

The present study expands the level of knowledge carried out by the previous authors regarding this rare on a European level habitat type. It provides also data on the floristic composition and ecological preferences, as well as new information on its geographical range and area of occupancy, especially for Bulgaria. Furthermore, the factors determining its occurrence are pointed out and some remarks for its conservation are also proposed.

\section{Material and methods}

The plant communities of species complex Genista lydia/G. rumelica were investigated during the vegetation seasons of 2016-2017. The principles and methods of this study follow the Braun-Blanquet's phytosociological school (Braun-Blanquet 1964, Mueller-Dombois \& Ellenberg 1974). At each sampling plot the complete list of the present species (vascular plants) was recorded together with their cover-abundance values according to the 9-degree Braun-Blanquet scale, based on Barkman et al. (1964) (see Westhoff \& van der Maarel 1980). The complete checklist of species and the study of ecological features are based on these sample plots. The taxonomic nomenclature of the vascular plants generally follows Delipavlov \& Chesmedzhiev (2003). However, in the case of absence of sufficient information, misapplied names or different taxonomic combinations referred to a certain taxon, some additional literature was used, mostly from other Bulgarian floristic works (Jordanov 19631979, Velčev 1982, 1989, Kožuharov 1992, 1995, Assyov et al. 2012, Peev 2013) as well as and occasionally online databases (ILDIS World Database of Legumes 2010, The Plant List 2013, Euro+Med PlantBase 2018). The floristic elements (or geoelements) are indicated in accordance with Assyov et al. (2012) and are subsequently united in 10 larger categories for better understanding of some general trends in their distribution (see Tzonev 2002). The plant life-forms of the species are presented using the classification of Raunkiaer (1934). The soil types and composition of the bedrock outcrops are presented in accordance with the map of the soils of Bulgaria (Ninov 2002) and also the geological map (Cheshitev \& Kânčev 1989). The map of habitat's distribution was produced using the Quantum GIS application (http://www. qgis. org/) and Google Earth Pro (https://www.google.com/ earth/download/gep/agree.html). The conservation status of the taxa from the floristic composition of studied habitat is according to Petrova \& Vladimirov (2009). Their protected status is indicated in accordance with the Appendix 3 of the Bulgarian Biological Diversity Act (2002). The enlisted endemic taxa are presented according to Petrova \& Vladimirov (2010) and Assyov et al. (2012), Euro+Med PlantBase (2018). 


\section{Results and Discussion}

\section{Distribution}

The communities dominated by Genista lydia/G. rumelica have limited distribution on the territory of Bulgaria. The most significant areas occupied by this habitat type are the slopes of Pirin, Rila and Western Rhodope Mts. as well as the neighboring valley of Mesta River (close to the towns of Gotse Delchev and Dobrinishte) and the Eastern Rhodope Mts., along the valleys of Vurbitsa and Arda Rivers (near the villages of Podkova and Sedlovina). In Central Rhodope Mts., (between the towns of Devin and Chepelare), the habitat type occurs with less coverage of the plant communities. The northernmost spread of the communities on the territory of Bulgaria occupy the southern slopes of the Eastern Balkan Range (above the town of Sliven) (see Figure 2). The habitat's localities on the southern slopes of the Central Balkan Range (Kazanlak town), Sredna Gora Mts. (Pazardzhik region), Slavyanka (Orvilos) Mts. (South-western Bulgaria) and
Strandzha Mts. published on the map in the Red Data Book of Bulgaria, vol. 3 (Gussev \& Tzonev 2015) were not confirmed during the field work. The localities at $\mathrm{Du}-$ brash region of the Rhodope Mts. (Bondev 2002) are also unconfirmed.

\section{Floristic composition}

About 500 taxa belonging to 238 genera and 56 plant families were found to participate in the habitat's floristic structure (see the Appendix). The richest families are Fabaceae (65 taxa), followed by Asteraceae (59), Poaceae (54), Caryophylaceae (42) etc. Trifolium is the genus with the highest number of species and subspecies (25), followed by Vicia and Silene (13), Sedum (11), Potentilla (8), etc. The studied plant communities are relatively rich in species: from 16 to 79 per plot (mean 43).

The flowering period for Genista lydia/G. rumelica starts at the end of April in the Eastern Rhodopean stands, which are located at the lowest altitude and ends in mid-June for those from the Central Rhodopes.

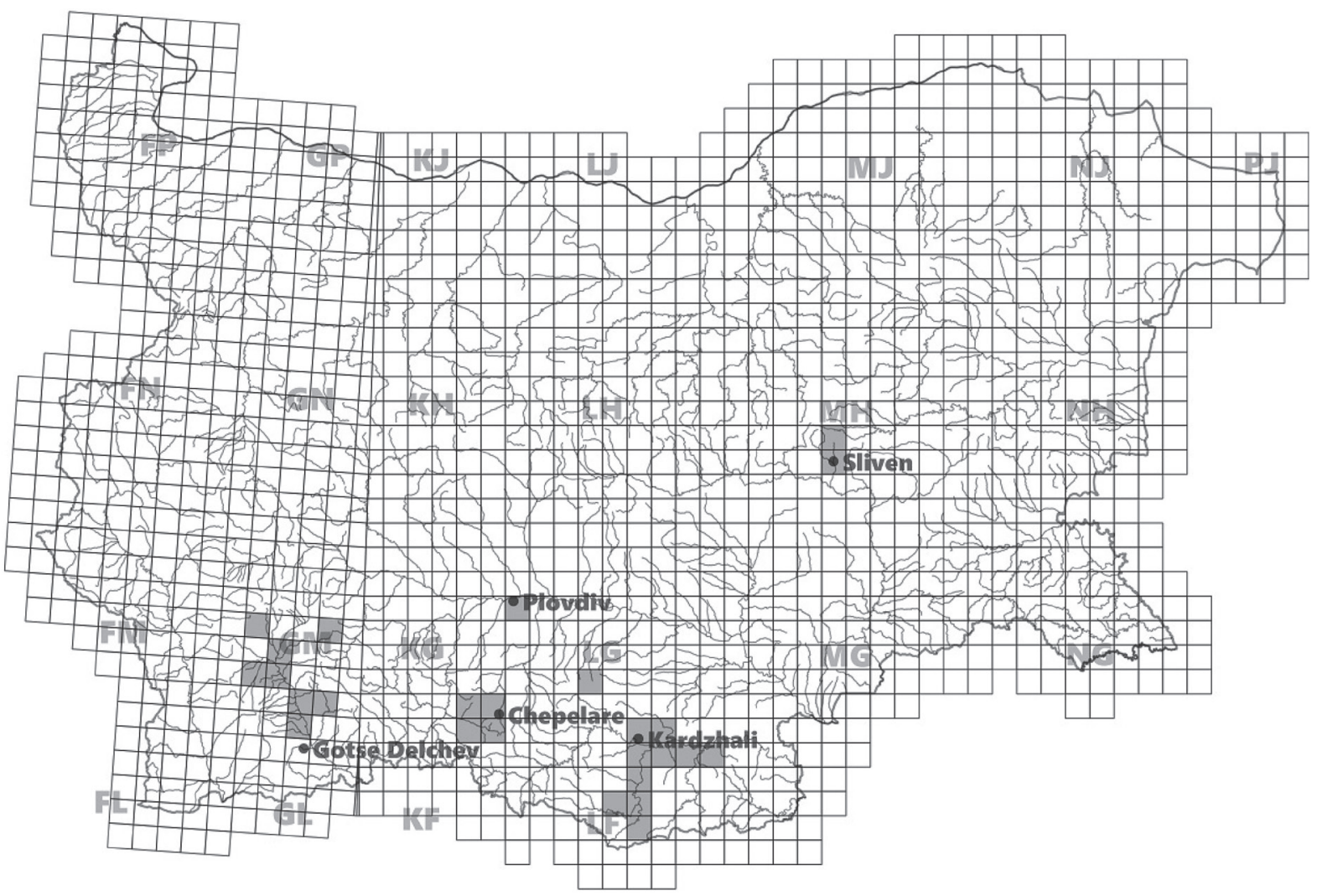

Figure 2: Map of distribution of communities of Genista lydia/G. rumelica in Bulgaria (10×10 km UTM grid scale). The presence of the habitat in the grid cells is marked in grey color.

Slika 2: Karta razširjenosti združb vrst Genista lydia/G. rumelica v Bolgariji (kvadranti 10×10 km UTM). Prisotnost habitata v kvadrantu je prikazana s sivo barvo. 
During the flowering season the communities are easily identifiable due to the yellow aspect of the areas occupied by them. Therefore, it is the most suitable period for their mapping. The stands of the Genista lydia complex include species characteristic to different types of dry grasslands: Koeleria nitidula, Anthoxanthum odoratum, Chrysopogon gryllus, Festuca valesiaca, Melica ciliata, Dichanthium ischaemum as well as the annuals Poa bulbosa, Vulpia ciliata, Vulpia myurus, Aira elegantissima, Aegilops triuncialis, Galium divaricatum, Bromus squarrosus, Trifolium arvense, etc. At higher altitudes and under more mesophilic conditions other common species could be also Arrhenatherum elatius, Cynosurus cristatus, Agrostis capillaris, Holcus lanatus, etc. Other species with a high constancy are Achillea coarctata, Asperula tenella, Cruciata pedemontana, Eryngium campestre, Euphorbia cyparissias, Galium verum, Hieracium hoppeanum, Hypericum perforatum, Luzula campestris, Moenchia mantica, Myosotis ramosissima, Cerastium glomeratum, Plantago lanceolata, Potentilla argentea, Rumex acetosella, Sanguisorba minor, Trifolium campestre, Thymus spp., Viola tricolor. Various Balkan endemics species like Dianthus pinifolius ssp. pinifolius, Silene frivaldszkyana, Anthemis macedonica, Verbascum humile, Viola aetolica, Trifolium trichopterum, Sesleria latifolia, Achillea coarctata, Sedum grisebachii, Sempervivum leucanthum, Digitalis viridiflora, Cerastium petricola could be also found in the floristic composition of these communities. However, they are not so common. Some of them have also protected status according to the Bulgarian Biodiversity Act (enlisted in the Annex 3) - Anthemis virescens, Campanula jordanovii, Sedum stefčo, Romulea linaresii ssp. graeca, etc. In Western Rhodopes and Pirin Mts., the dominant species are established to participate in mixed communities co-dominated from another Balkan endemic shrub - Chamaecytisus absinthioides. Other shrubs like Juniperus communis, J. deltoides, Rosa spp., Genista carinalis, Cistus incanus, Paliurus spina-christi, etc. also participate in their floristic structure. In more chasmophytic communities of the Eastern Balkan Mts., Lembotropis nigricans and Syringa vulgaris also could be found as co-dominants. In few plots, single individuals of some adventive species from the adjacent crop fields like the lavender (Lavandula angustifolia) were also observed. Some trees could occasionally participate in the floristic structure of these communities. In abandoned or occasionally grazed stands, some juvenile individuals from the surrounding forest vegetation could penetrate in the communities of Genista spp. Such species are Quercus spp, Carpinus orientalis, Pinus nigra, P. sylvestris, Pyrus pyraster, Crataegus monogyna, Acer tataricum, Corylus avellana, etc.

\section{Ecological preferences and structure of the communities}

Genista lydia and G. rumelica, generally prefer the more extreme conditions of the sheer rocks, rock crevices and stone terraces, therefor they could be described as chasmophytes. The secondary expansion of their communities is initiated mainly due to the habitat degradation as a result of deforestation, soil erosion or/and extensive livestock farming. These communities occupy mainly areas where there is some kind of disturbance of the primary dominant vegetation types. They could be found in territories actively used as pastures where, due to the overgrazing and trampling, the occurrence of grasses is suppressed. In the overgrazed areas the coverage of the dominant species is higher and vice versa. The communities of G. lydia complex could also occupy secondarily degraded areas: screes and eroded places which have replaced some destroyed or degraded oak (Quercus frainetto, Q. pubescens, Q. delechampii) and Black pine (Pinus nigra) forests. But at a higher elevation they could be also in places of European beech (Fagus sylvatica), Scot's pine (Pinus sylvestris) and Norway spruce (Picea abies) forests. These communities could also occupy mining deposits, open rocky slopes above the rivers, deep ravines and even eroded sides along the motorways as well as the sandy alluviums on the higher banks of rivers. They could even occasionally inhabit some recently abandoned crop fields formerly used for the cultivation of tobacco and lavender. This habitat type is also typical for steep, dry, stony and sunny localities with shallow soils, predominantly Lithic and Umbric Leptosols or Dystric Cambisols, and rarely on Eutric Fluvisols. The rocky outcrops are often composed from different magmatic rocks and minerals like volcanic tuffs, andesites, rhyolites and zeolites. However, this vegetation type also could be found on sandstones, schists, conglomerates and gneisses.

The present fieldwork did not confirm the preferences of the dominant species to the cretaceous substrates as it was presented in the published literature (Gussev \& Tzonev 2015, Janssen et al. 2016, EUNIS habitat classification 2017). On the limestone terrains the species from the dominant complex, Genista lydia or G. rumel$i c a$, were observed only as solitary individuals or small groups with a scattered occurence. Jakucs (1960) have described forests of Quercus pubescens from the calcareous slopes of Golo Burdo Mts., Western Bulgaria, where G. lydia was found to dominate in the shrub layer. This is probably a case of misidentification with $G$. januensis (syn.: G. triangularis Willd) which is a common species on limestone substrates in the western part of the country (see Apostolova-Stoyanova \& Stoyanov 2009). According to our experience, closed and homogeneous 
communities of the studied habitat type are established exclusively on volcanic rocks. It is especially wherever a certain amount of deposits accumulates as dust, sand and fine dried plant litter. Also they could be found at places composed by shallow soils with sandy structure. Contrary, the bare calcareous terrains with a high level of erosion normally are presented by larger stones and deposits which consist from gravel or larger particles. Such types of substrates are probably inappropriate for the spread of the communities discussed here.

The studied communities are mostly with open or semi-open and rarely almost closed coverage. Their structure is rather mosaic, consisting of patches with a different size $\left(20-200 \mathrm{~m}^{2}\right)$. In some places their coverage is closed and homogenous, overgrowing entire hillsides. The total vegetation cover varies in the range between $50 \%$ and $98 \%$ per plot (mean $80.5 \%$ ). However, the cover of cryptograms is abundant in many of the studied stands. The areas with southern exposition $(65.9 \%)$, predominate to those with northern $(26.4 \%)$. The inclination varies between $1^{\circ}-60^{\circ}$, (mean $\left.10.4^{\circ}\right)$. The altitudinal range is between 150 and $1500 \mathrm{~m}$ (see Table 1). Most of the habitat's areas fall into the climatic zone of Continental-Mediterranean region. Only the Eastern Balkan stands falls into the Transitional-Continental region (Velev 2002). According to Bondev (2002) the territories occupied by the studied communities belong to the Illyrian (Balkan) and Macedoninan-Thracian provinces of the European deciduous forest region.

Table 1: Parameter values for the vegetation cover, exposition, inclination and altitude of the studied habitat type. The plot numbers are bolded.

Tabela 1: Vrednosti za pokrovnost vegetacije, smer neba, naklon in nadmorsko višino za obravnavani habitatni tip. Število ploskev je prikazano krepko.

Following the regional differences, the habitat could be split into three main habitat sub-types - A) Chas- mophytic (Balkan), B) East Rhodopean (Thracian) and C) Rilo-Rhodopean. This separation is based on the variations in the communities depending from their features like the distribution, altitude, inclination of the terrains, soil types, basic rocks and floristic composition.

A) The Chasmophytic habitat sub-type (Figure 3) is represented mostly by chasmophytic communities occurring on acidic rocks (andesites, diorites, conglomerates) at the slopes of the East Balkan Range (Sliven).

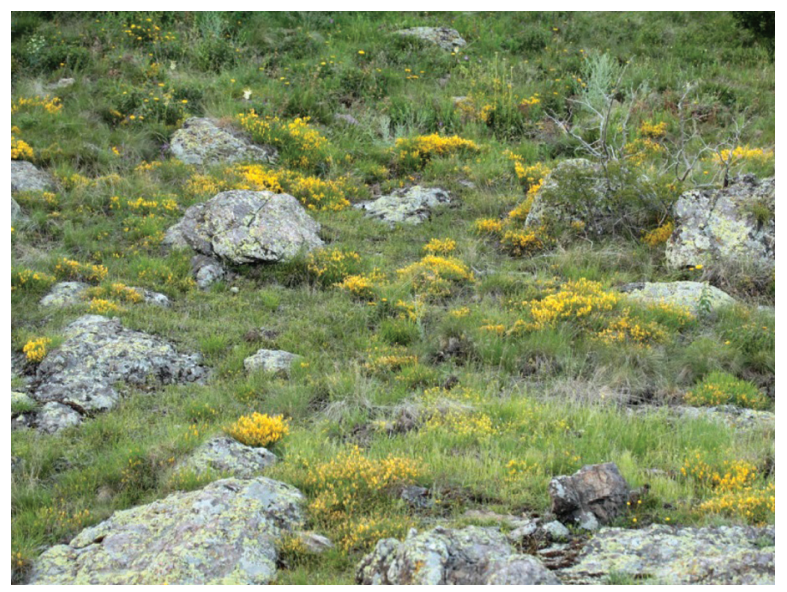

Figure 3: Appearance of the Chasmophytic habitat sub-type, Sliven district, East Balkan range.

Slika 3: Hazmofitski habitatni podtip, Sliven, gorovje Vzhodni Balkan.

These communities inhabit mostly rock cliffs and terraces with a predominantly southern exposition, and occupied areas between $15-50 \mathrm{~m}^{2}$. The soils are shallow Umbric Leptosols. The mean number of species per plot (29) is the lowest among the identified habitat sub-types due to the extreme ecological conditions. The mean value of the total vegetation cover is also the lowest one: $63 \%$ per plot. Species with high constancy are Anthemis cretica, Sempervivum marmoreum, Galium flavescens, Hypericum montbretii, Festuca dalmatica, Bellardiochloa violacea, Potentilla rupestris, Seseli rigidum, Viscaria vulgaris ssp. atropurpurea, etc (see Table 2).

\begin{tabular}{|c|c|c|c|c|c|}
\hline \multirow{4}{*}{ 흉 } & \multicolumn{4}{|c|}{ Vegetation cover $(\%)$} & \multirow{3}{*}{$\begin{array}{c}\text { Mean vegetation cover } \\
(80.5 \%)\end{array}$} \\
\hline & $50-60 \%$ & $61-75 \%$ & $76-90 \%$ & $>91 \%$ & \\
\hline & $20(15.5 \%)$ & $19(14.7 \%)$ & $68(52.7 \%)$ & $22(17.1 \%)$ & \\
\hline & \multicolumn{4}{|c|}{ Exposition } & \\
\hline \multirow{8}{*}{ 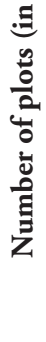 } & S, SW,SE & N,NW,NE & W & $\mathrm{E}$ & \\
\hline & $85(65.9 \%)$ & $34(26.4 \%)$ & $8(6.2 \%)$ & $2(1.6 \%)$ & \\
\hline & \multicolumn{4}{|c|}{ Inclination $\left(\right.$ degrees $\left.^{\circ}\right)$} & \multirow{3}{*}{$\begin{array}{l}\text { Mean inclination value } \\
\qquad\left(10.4^{\circ}\right)\end{array}$} \\
\hline & $1^{\circ}-10^{\circ}$ & $11^{\circ}-20^{\circ}$ & $20^{\circ}-30^{\circ}$ & $>31^{\circ}$ & \\
\hline & $99(76.7 \%)$ & $9(7 \%)$ & $10(7.8 \%)$ & $11(8.5 \%)$ & \\
\hline & \multicolumn{4}{|c|}{ Altitude (meters) } & \multirow{3}{*}{$\begin{array}{l}\text { Average altitude } \\
\quad(698.9 \mathrm{~m})\end{array}$} \\
\hline & $0-400$ & $400-800$ & $800-1200$ & $>1200$ & \\
\hline & $47(36.4 \%)$ & $32(24.8 \%)$ & $37(28.7 \%)$ & $13(10.1 \%)$ & \\
\hline
\end{tabular}


Table 2: Synoptic table of the studied habitat sub-types with constancy displayed in classes and as percentage. Only species in constancy classes III or higher ( $>40 \%)$, at least for one of the sub-habitat types are shown in the table.

Tabela 2: Sinoptična tabela obravnavanih habitatnih podtipov s prikazano stalnostjo v razredih in z odstotki. Prikazane so samo vrste $\mathrm{z}$ razredom stalnosti III ali večjo stalnostjo $(>40 \%)$ v vsaj enem od habitatnih podtipov.

\begin{tabular}{|c|c|c|c|c|c|c|c|c|}
\hline \multirow{2}{*}{$\begin{array}{c}\text { Habitat subtype } \\
\text { Constnacy: class/\% } \\
\end{array}$} & \multicolumn{2}{|c|}{$\begin{array}{l}\text { S3-43. Rilo-Rhodopean } \\
\text { submontane } \\
\text { genistoid scrub } \\
\text { (Rilo-Rhodopean) }\end{array}$} & \multicolumn{2}{|c|}{$\begin{array}{l}\text { S3-42. Thracian } \\
\text { submontane } \\
\text { genistoid scrub } \\
\text { (Eastern Rhodopean) }\end{array}$} & \multicolumn{2}{|c|}{$\begin{array}{l}\text { S3-41. Balkan-Range } \\
\text { submontane } \\
\text { genistoid scrub } \\
\text { (Chasmophytic) }\end{array}$} & \multicolumn{2}{|c|}{$\begin{array}{l}\text { All Habitat } \\
\text { subtypes }\end{array}$} \\
\hline & class & $\%$ & class & $\%$ & class & $\%$ & class & $\%$ \\
\hline Genista lydia/G. rumelica & $\mathrm{V}$ & 100 & $\mathrm{~V}$ & 100 & $\mathrm{~V}$ & 100 & $\mathrm{~V}$ & 100 \\
\hline Eryngium campestre & IV & 61 & $\mathrm{~V}$ & 83 & II & 25 & IV & 64 \\
\hline Poa bulbosa & III & 46 & IV & 79 & II & 31 & III & 55 \\
\hline Festuca valesiaca & IV & 77 & II & 36 & I & $\mathbf{0}$ & III & 54 \\
\hline Sanguisorba minor & III & 48 & IV & 74 & I & 13 & III & 52 \\
\hline Asperula tenella & IV & 69 & II & 36 & II & 6 & III & 50 \\
\hline Cruciata pedemontana & III & 55 & III & 45 & I & $\mathbf{0}$ & III & 45 \\
\hline Rumex acetosella & II & 32 & IV & 67 & III & 44 & III & 45 \\
\hline Teucrium chamaedrys & III & 56 & II & 38 & I & $\mathbf{0}$ & III & 43 \\
\hline Anthoxanthum odoratum & II & 28 & IV & 74 & II & 31 & III & 43 \\
\hline Plantago lanceolata & III & 46 & III & 50 & $\mathrm{I}$ & $\mathbf{0}$ & III & 42 \\
\hline Trifolium campestre & IV & 61 & II & 24 & I & 6 & III & 42 \\
\hline Hieracium hoppeanum & III & 48 & II & 31 & II & 38 & III & 41 \\
\hline Trifolium arvense & III & 45 & II & 29 & II & 38 & II & 39 \\
\hline Centaurea cuneifolia & III & 41 & III & 43 & I & 13 & II & 38 \\
\hline Bromus squarrosus & III & 52 & I & 19 & I & 13 & II & 36 \\
\hline Euphorbia cyparissias & III & 41 & II & 24 & III & 50 & II & 36 \\
\hline Agrostis capillaris & III & 59 & I & $\mathbf{0}$ & I & 19 & II & 35 \\
\hline Dichanthium ischaemum & III & 38 & II & 38 & I & 6 & II & 34 \\
\hline Galium verum & III & 35 & III & 45 & I & $\mathbf{0}$ & II & 34 \\
\hline Chrysopogon gryllus & I & 20 & IV & 67 & I & 13 & II & 34 \\
\hline Thymus glabrescens & II & 31 & III & 43 & I & $\mathbf{0}$ & II & 31 \\
\hline Orlaya grandiflora & $\mathrm{I}$ & 20 & $\mathrm{I}$ & 19 & III & 56 & II & 24 \\
\hline Thymus longicaulis & III & 52 & $\mathrm{I}$ & 2 & II & 38 & II & 34 \\
\hline Achillea coarctata & III & 48 & I & 2 & III & 44 & II & 33 \\
\hline Scabiosa triniifolia & III & 41 & I & 19 & II & 25 & II & 32 \\
\hline Potentilla argentea & III & 41 & II & 26 & I & $\mathbf{0}$ & II & 31 \\
\hline Koeleria macrantha & III & 52 & I & $\mathbf{0}$ & I & 13 & II & 30 \\
\hline Plantago subulata & III & 41 & I & $\mathbf{0}$ & IV & 63 & II & 30 \\
\hline Potentilla neglecta & III & 46 & I & 10 & I & 6 & II & 29 \\
\hline Dianthus pinifolius ssp. pinifolius & III & 45 & I & 5 & I & 6 & II & 27 \\
\hline Phleum montanum & III & 41 & $\mathrm{I}$ & $\mathbf{0}$ & II & 31 & II & 26 \\
\hline Aira elegantissima & II & 25 & IV & 62 & I & $\mathbf{0}$ & II & 34 \\
\hline Moenchia mantica & I & 11 & III & 52 & I & $\mathbf{0}$ & II & 23 \\
\hline Euphorbia seguieriana & I & $\mathbf{0}$ & III & 55 & I & 19 & I & 20 \\
\hline Carlina vulgaris & I & 4 & III & 48 & I & $\mathbf{0}$ & I & 18 \\
\hline Geranium molle & I & 8 & III & 40 & I & $\mathbf{0}$ & I & 18 \\
\hline Sherardia arvensis & I & 4 & III & 45 & I & $\mathbf{0}$ & I & 17 \\
\hline Crepis setosa & I & 3 & III & 43 & I & 13 & I & 17 \\
\hline Oenanthe pimpinelloides & I & $\mathbf{0}$ & III & 48 & I & $\mathbf{0}$ & I & 16 \\
\hline Ranunculus millefoliatus & I & $\mathbf{0}$ & III & 45 & I & $\mathbf{0}$ & I & 15 \\
\hline Daucus guttatus ssp. zahariadii & I & 3 & III & 41 & $\mathrm{I}$ & $\mathbf{0}$ & I & 15 \\
\hline Linaria genistifolia ssp. genistifolia & I & 8 & I & 12 & III & 50 & I & 15 \\
\hline Koeleria nitidula & I & $\mathbf{0}$ & II & 21 & III & 44 & I & 12 \\
\hline Ornithogalum kochii & I & 6 & I & 7 & III & 44 & I & 11 \\
\hline Festuca dalmatica & I & 4 & I & $\mathbf{0}$ & III & 56 & I & 9 \\
\hline Anthemis cretica & I & $\mathbf{0}$ & I & $\mathbf{0}$ & IV & 63 & I & 8 \\
\hline Sempervivum marmoreum & I & $\mathbf{0}$ & I & $\mathbf{0}$ & III & 44 & I & 5 \\
\hline Viola kitaibeliana & $\mathrm{I}$ & $\mathbf{0}$ & $\mathrm{I}$ & $\mathbf{0}$ & III & 44 & $\mathrm{I}$ & 5 \\
\hline
\end{tabular}


These communities are also rich in Balkan endemics like Sesleria latifolia, Sempervivum erythraeum, Verbascum humile, Chamaecytisus calcareus, Scabiosa triniifolia, Silene lerchenfeldiana. On the other hand, the therophytes are less in numbers comparing to the following two sub-

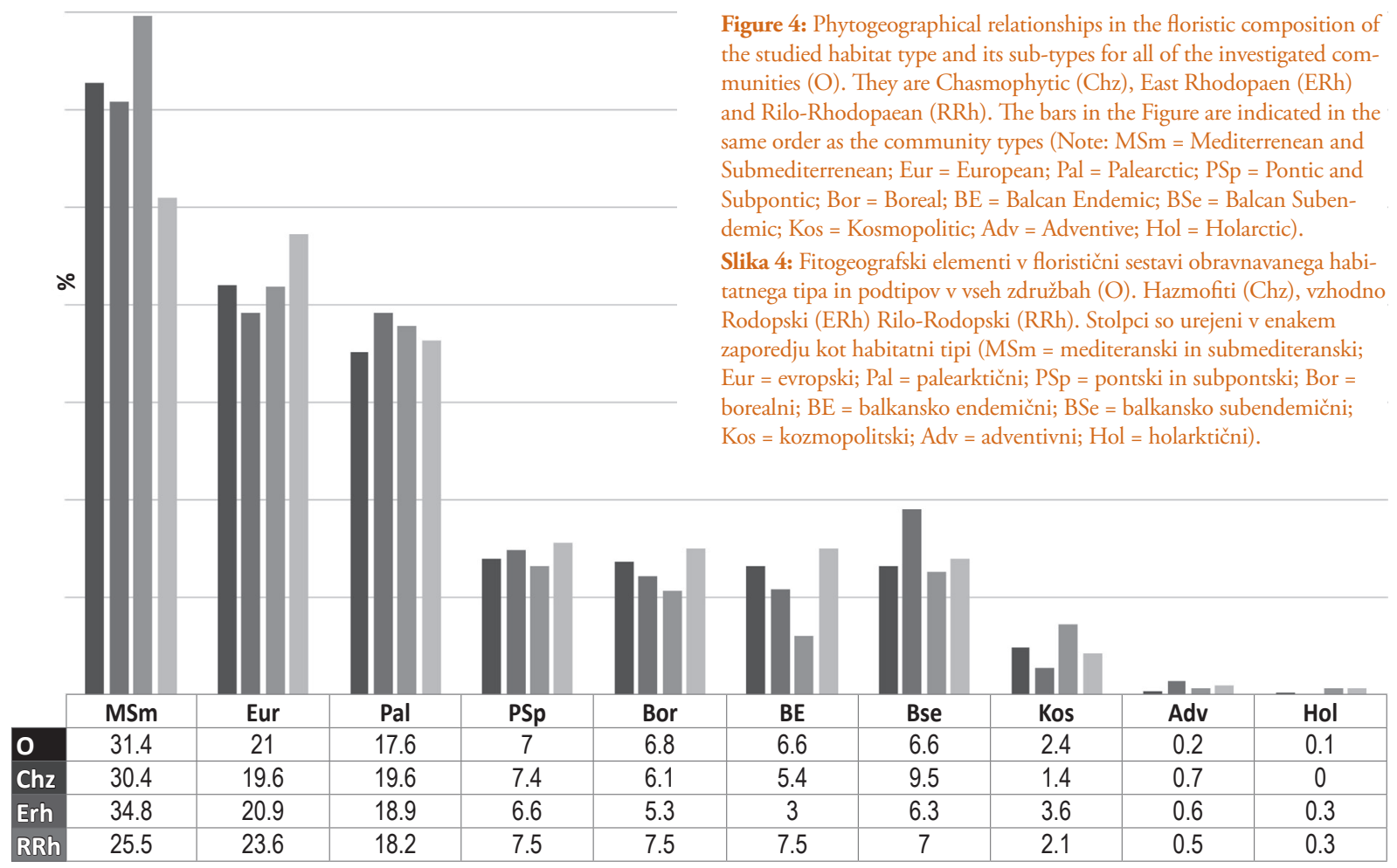

types (see Figures 4 and 5). Two species fom the floristic composition have conservation significance - the local endemic Campanula jordanovii (VU) and Tulipa australis (NT). They are also protected under the Annex 3 of Bulgarian Biodiversity Act.

Figure 4: Phytogeographical relationships in the floristic composition of Submediterrenean $;$ Eur $=$ European $;$ Pal $=$ Palearctic $:$ PSp $=$ Pontic and Subpontic; Bor $=$ Boreal; $\mathrm{BE}=$ Balcan Endemic; $\mathrm{BSe}=$ Balcan SubenKosmopolitic; Adv = Adventive; $\mathrm{Hol}=$ Holarctic . tatnega tipa in podtipov v vseh združbah (O). Hazmofiti (Chz), vzhodno Rodopski (ERh) Rilo-Rodopski (RRh). Stolpci so urejeni v enakem orealni. $\mathrm{BE}=$ balkansko endemični. $\mathrm{BSe}=$ balkansko subendemični; Kos = kozmopolitski; $\mathrm{Adv}=$ adventivni; $\mathrm{Hol}=$ holarktični).

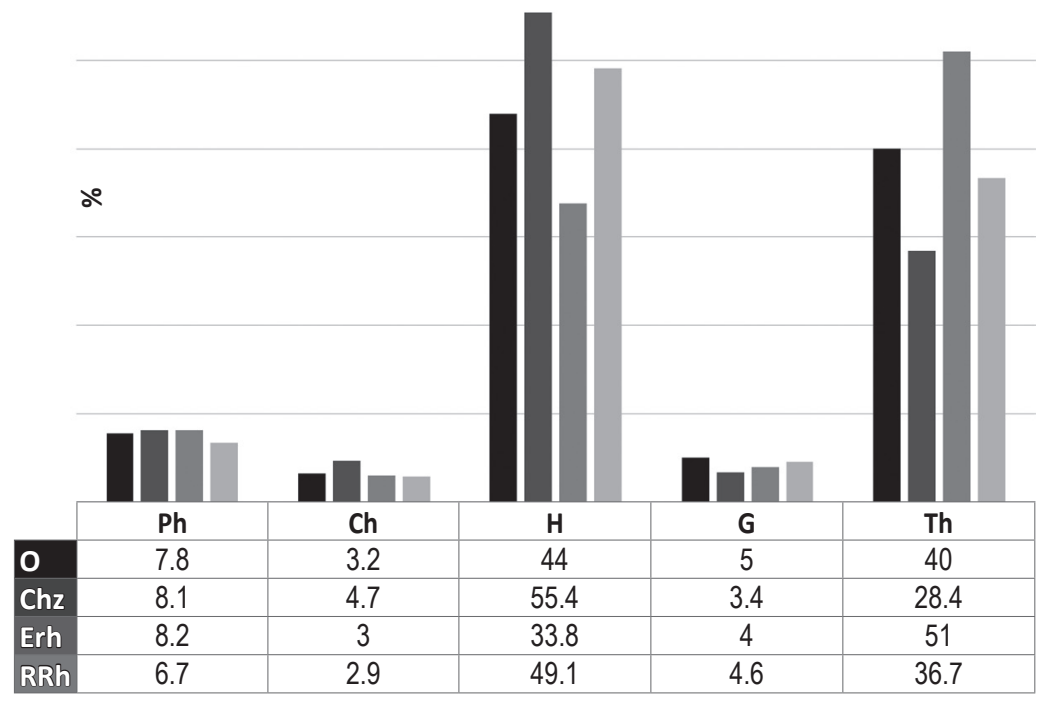

Figure 5: Spectrum of plant life-forms (Ph - phanerophytes, Ch - chamaephytes, H - hemicryptophytes, G - geophytes, Th - therophytes) amongst the researched habitat sub-types for all investigated sub-types (O); Chasmophytic (Chz), East Rhodopaen (ERh) and Rilo-Rhodopaean (RRh). The bars in the Figure are ordered in the same way as in the legend.

Slika 5: Spekter življenskih oblik ( $\mathrm{Ph}$ - fanerofiti, $\mathrm{Ch}$ - hamefiti, $\mathrm{H}$ - hemikriptofiti, G - geofiti, Th - terofiti) v obravnavanih habitatnih podtipih $(\mathrm{O})$; hazmofitski (Chz), vzhodno rodopski (ERh) in Rilo-rodopski (RRh). Stolpci so v enakem zaporedju kot poimenovanja v legendi. 


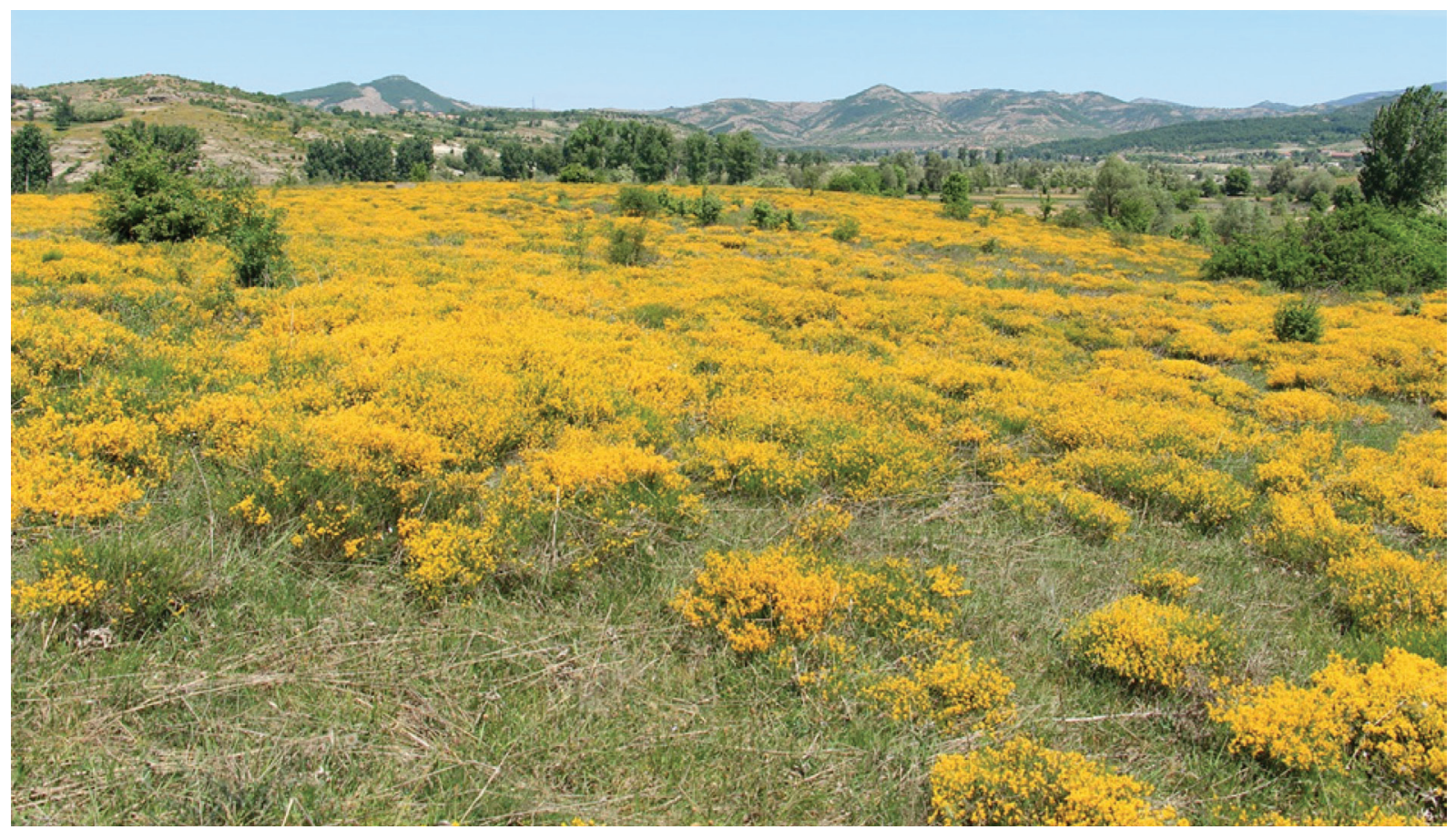

Figure 6: East Rhodopean stands of the studied communities.

B) The Eastern Rhodopean (Thracian) habitat subtype (Figure 6) is spread on schist, sandstones, tuffs or sand alluviums in the basin of Arda River between 160$390 \mathrm{~m}$ alt. Around the village of Sedlovina these communities have their own specificity. They could occupy substrates comprising almost entirely of white zeolites and mining deposits, which remained after their processing. In the vicinity of the village of Podkova, this habitat sub-type covers significant areas. The soil types are Lithic and Umbric Leptosols, but along the rivers, these communities also occupy the Eutric Fluvisols. Here the sub-Mediterranean climatic influence is considerable, promoting the richest floristic structure amongst the studied communities, where the therophytes with a typical Mediterranean origin dominate (see Figures 4 and 5). In early spring the herbaceous layer is dominated by geophytes like Romulea linaresii ssp. graeca, Ornithogalum spp., Crocus chrysanthus, reaching significant cover at some of the plots. The late spring aspect is rich in therophytes like many annual clovers. From mid-June, the aspect is dominated by grasses like Chrysopogon gryllus, Dichanthium ischaemum and some yellow flowering composites like Crepis setosa, Hypochaeris glabra, etc. The slopes with lower inclination are most prominent. Characteristic species are Euphorbia seguieriana, Oenanthe pimpinelloides, Trifolium tenuifolium. Other constant species are Poa bulbosa, Chrysopogon gryllus, Anthoxanthum odoratum, Aira elegantissima, Carlina vulgaris,
Slika 6: Sestoji obravnavanih združb v Vzhodnih Rodopih.

Crepis setosa, Ranunculus millefoliatus, Tuberaria guttata (see Table 2). The endemics are not as well presented as in the other two habitat sub-types. Balkan endemics are Armeria rumelica, Chamaecytisus jankae, Daucus guttatus ssp. zahariadii, Dianthus corymbosus, Anthemis virescens, Romulea linaresii ssp. graeca. The last two taxa are also included in the Red List of Bulgarian vascular plants (Petrova \& Vladimirov 2009) and Annex 3 of the Bulgarian Biodiversity Act as respectively Endangered (EN) and Vulnerable (VU).

C) Amongst the three habitat sub-types, The RiloRhodopean habitat sub-type covers the largest territories (Figure 7). They are found in the Mesta River valley and with more limited distribution in the Central Rhodope Mts. The bedrock varies but mostly there are rhyolites, volcanic schists, gneisses, sandstones, conglomerates. The soil types are represented by Umbric Leptosols and Dystric Cambisols. The altitudinal range is between 600 and $1500 \mathrm{~m}$ alt. The slopes are mostly facing south with an average inclination of $15 \%$, which is the highest among the habitat sub-types. The floristic elements with Mediterranean origin are the most widespread and the geoelements of European and Boreal origins are more prominent than those in the previously described community sub-types (see Figure 4). This could be explained with the higher altitudes and the influence of the montane climate. Species with high constancy are Thymus longicaulis, Achillea coarctata, Agrostis capillaris, 


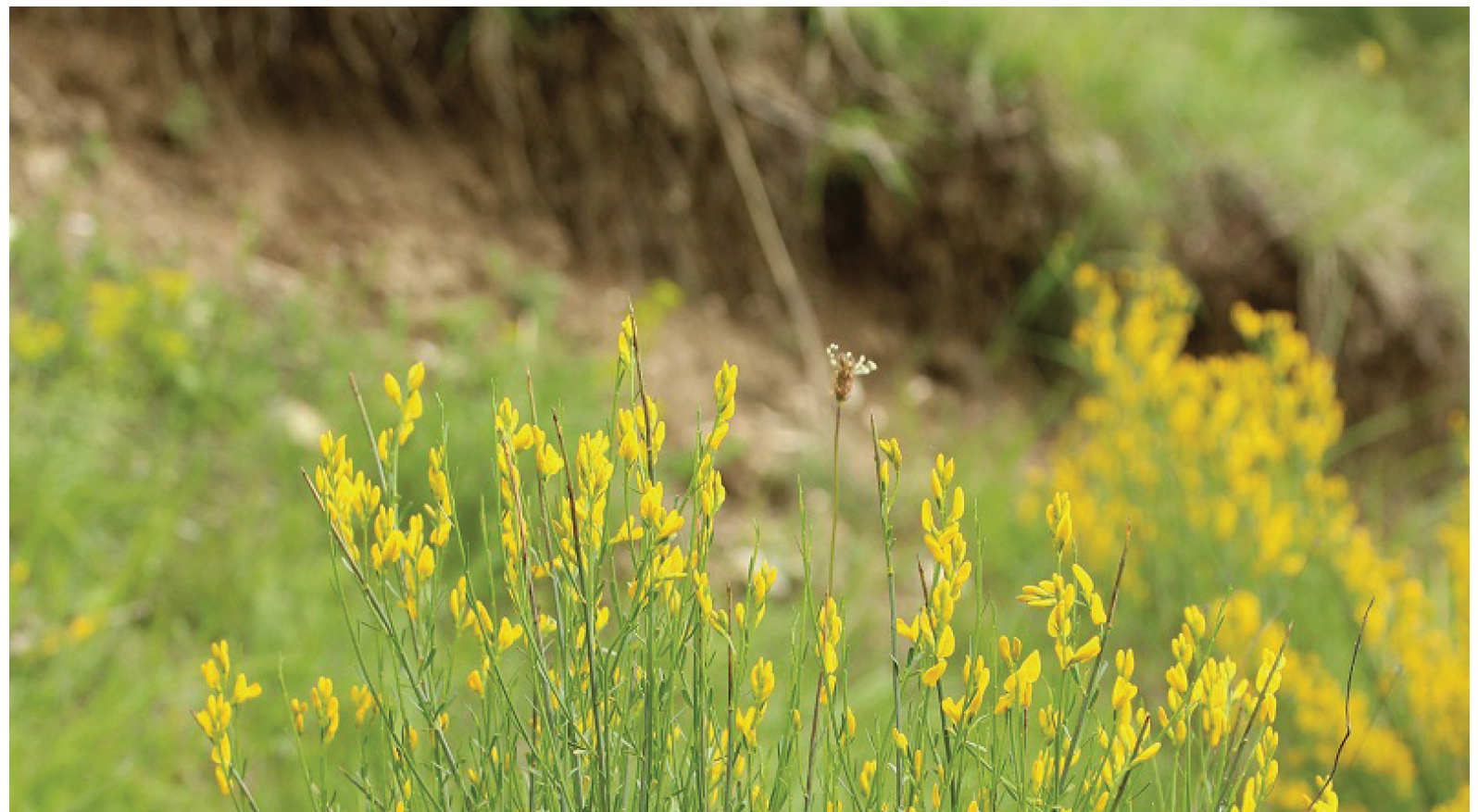

Figure 7: The Rilo-Rhodopean habitat sub-type, vicinities of Dobrinishte town, West Rhodopes Mts. Slika 7: Rilo-rodopski habtatni podtip iz okolice mesta Dobrinishte, gorovje Zahodni Rodopi.

Dianthus pinifolius ssp. pinfolius, Scabiosa triniifolia, Sedum grisebachii, Hypericum rumeliacum. Other common species are Festuca valesiaca, Trifolium campestre, Bromus squarrosus, Koeleria macrantha, Plantago subulata, Hieracium hoppeanum, Potentilla neglecta, Phleum montanum, Minuartia hirsuta ssp. falcata (see Table 2). The floristic composition of the Rilo-Rhodopean communities is the richest in Balkan endemic species comparing with the other identified habitat sub-types. Typical endemic and sub-endemic species are Digitalis viridiflora, Viola aetolica, Chamaecytisus absinthioides, Verbascum humile, Dianthus moesiacus ssp. moesiacus, Cerastium petricola, Trifolium trichopterum, Silene velenovskyana, S. frivaldszkyana, Asyneuma anthericoides, Sempervivum erythraeum, S. leucanthum, Campanula sparsa, C. scutellata, Anthemis macedonica, etc. According to Petrova \& Vladimirov (2009), two taxa - Sedum stefčo and Orchis papilionacea are evaluated as Vulnerable (VU) and are protected under Annex 3 of the Bulgarian Biodiversity Act.

\section{Area of coverage and sort of impact}

The total area of $5.2 \mathrm{~km}^{2}$ covered by the studied habitat type was mapped during the field work. AOO is 26 $\left(2600 \mathrm{~km}^{2}\right)$ (Figure 2), EOO is about $9670 \mathrm{~km}^{2}$. The estimated coverage is far below the established values in the European Red List of Habitats (Janssen et al. 2016).
The areas occupied by the habitat are close to the settlements. They are under continuous human impact related to the traditional practices of extensive livestock farming. Most of these territories are primarily used as pastures where the overgrazing, over-trampling, deforestation and the erosion seem to favor the expansion of these plant communities. There was not observed the direct effect of grazing on the dominants in the examined plots. However, the spread and sowing of Genista seeds is probably assisted by livestock movement and trampling. The established effects of recent fires were assessed as a positive for the expansion of Genista populations in two of the localities, due to the elimination of the strong competition of grasses and forbs as well as the slow-growing shrubs. According to our experience, the main factor leading to decline of the habitat's area is abandonment of grazing. The communities are more closed and homogeneous covering larger areas in the places with active grazing, while in the areas with occasional or without grazing, they have lower density and are represented by small stands with a mosaic distribution. In habitat's sites, overgrown by perennial grasses, thorny shrubs or low trees, many individuals from the dominant complex were found morbid and significantly infected by Cuscuta spp. Therefore it could be conclude that $G$. lydia and G. rumelica are poor competitors and their communities are depending from the grazing or other types of disturbances. Although 
some areas occupied by these communities are located on continuosly abandoned agricultural lands used as pastures at the present, now these lands are ploughed again due to the subsidies for farming coming from the European Agricultural Policy.

\section{Conservation measures}

Some of the stands of the studied vegetation type are located in the protected sites of the Natura 2000 ecological network ("Mesta River", "Rhodopes-Eastern", "Rhodopes -Western"). They also could be part of the vegetation cover of protected areas designinited according to the Bulgarian Protected Areas Act. Such territories are "Sinite Kamani" Nature Park, "Yumruk skala" Protected Area and "Pashovi Skali" Natural Monument. However, this vegetation type is not subject to special protection measures because it is not included in Annex I of the Habitats Directive and in the Bulgarian Biodiversity Act. Some proposed measures for its conservation are to be undertaken at national and European level. One of these measures should be their enlisting in Annex I of the Habitats Directive and Bulgarian Biodiversity Act. The designation of some most representative localities as protected areas is also necessary. This measure should be combined with regular monitoring and some kind of appropriate management, e.g. special grazing regime. It is in order to prevent the successional changes and decline of the habitat's areas.

The preferences of the dominant species to limestone substrates is not confirmed during this study. This should be reflected in the further revisions/editions of the "Red Data Book of Bulgaria, vol. 3 Natural habitats" and also of the European Red List of Habitats and EUNIS habitat classification. The establishment of habitat sub-types should also be indicated in the above-mentioned sources. We propose the following subdivision of the habitat S34. "Balkan-Anatolian submontane genistoid scrub:

S3-41. Balkan-Range submontane genistoid scrub

S3-42. Thracian submontane genistoid scrub

S3-43. Rilo-Rhodopean submontane genistoid scrub

Despite its limited area of occurrence it should be pointed that the habitat has a natural ability to expand its distribution to some secondary eroded terrains. The copious seed production and the fast growth of the dominant Genista species are the reasons for their rapid spread and overgrowth on many disturbed and pioneer sites like mining deposits, sand alluviums, abandoned crop fields, roadsides, etc. The preference of the dominant species to unstable substrates with a high level of erosion make these communities suitable for planting as anti-erosion vegetation, especially in the area of the eastern Mediterranean region.

\section{Conclusion}

The present study is the first one focused on the vegetation dominated by the species complex of $G$. lydia/G. rumelica in Bulgaria at the habitat level. It has confirmed some inference, done by previous authors and also contributes to the data on the diversity of floristic composition, ecological features and distribution on the national level of this vegetation type. The collected data emphasizes the typical Sub-Mediterranean origin and distribution of studied communities which are proven by the high occurrence of species with such origin $(31.4 \%)$ and also the significant number of therophytes, geophytes and chamaephytes ( $48.2 \%$ in total). The various altitudinal range of occurrence, the transitional climatic influences and the differences of the management of these areas are among the main reasons for their great floristic diversity - about 500 species participate in their floristic composition. The habitat has a large number of endemic species (33 Balkan endemics and the same number of Balkan subendemics), some of them also protected. It is together with the less territories occupied by these communities compared to the data from the European Red List, which emphasizes their conservation significance and level of vulnerability. The major threat to this habitat is the abandonment of traditional practices in the pastureland management and the changes in the land use. Such are also the transformation of pasturelands into crop fields or artificial forest plantations. After the abandonment of grazing, some rapid successional changes lead to the complete replacement of these heatlands by grassland and tall scrubland or even tree communities. Therefore some measures and specific maintenance should be applied in order to prevent habitat's decline.

\section{Acknowledgements}

The research was partly financed by the project: "Syntaxonomic characteristics of the Rumelian (Genista rumelica Velen.) and Lydian (Genista lydia Boiss.) communities in Bulgaria and North Greece". - Contract №80.1065/19.04.2018 funded by the Scientific Research Fund of the Sofia University "St. Kliment Ohridski"

Georgi Kunev (D), https://orcid.org/0000-0002-9363-3370 


\section{References}

Apostolova-Stoyanova, N. \& Stoyanov, S. 2009: Systematical and phytogeographical analysis of the flora on Mt Golo Bardo. Phytologia Balcanica 15(3): 401-430.

Asyov, B. \& Petrova, A. (eds.). 2012: Conspectus of the vascular plants in Bulgaria. Bulgarian Biodiversity Foundation, Sofia, 489 pp. [in Bulgarian].

Biological Diversity Act. 2002: State Gazette, Sofia, issue 77, August 2002, last amendment and addenda in issue 66, July 2013 [in Bulgarian].

Boissier, P. 1843: Genista lydia Boiss. In: Diagnoses plantarum Orientalium novarum. Typographia Ferd. Ramboz, Genevae, vol. 1(2), pp. 8-9.

Bondev, I. 1991: The vegetation of Bulgaria. Map M 1 : 600000 with explanatory text. Sofia Univ. Press, Sofia, 183 pp. [in Bulgarian].

Bondev, I. 2002: Geobotanic regionalization. In: Kopralev, I. (ed.): Geography of Bulgaria. ForCom, Sofia, pp. 336-352. [in Bulgarian].

Braun-Blanquet, J. 1964: Pflanzensoziologie. Grundzüge der Vegetationskunde. 3. ed. Springer Verlag, Wien, 865 pp.

Cheshitev, G. \& Kânčev, I. (eds). 1989: Geological map of Bulgaria $1: 500$ 000. Committee of Geology - Department of Geophysical prospecting and Geological Mapping, Sofia

Delipavlov, D. \& Chesmedzhiev, I. (eds). 2003: Key to the plants on Bulgaria. Agrarian University Acad. Press, Plovdiv, 591 pp. [in Bulgarian].

EUNIS habitat classification 2017 (Revised forest heathland scrub tundra). Published on the Internet: https://www.eea.europa.eu/dataand-maps/data/eunis-habitat-classification

Euro+Med (2006-): Euro+Med PlantBase - the information resource for Euro-Mediterranean plant diversity. Published on the Internet http://ww2.bgbm.org/EuroPlusMed/ [accessed July 2018].

Evstatieva, L., Christov, V. \& Neikov, N. 2004: Chemotaxonomic study of some species of genus Genista (Fabaceae). Cluster analysis. Phytologia Balcanica 10(1): 39-43.

Gibbs, P. 1968: Genista L. - In: Tutin, T. G. et al. (eds): Flora Europaea. Vol. 2, Cambridge Univ. Press, Cambridge, pp. 94-100.

ILDIS World Database of Legumes 2010. Published on the Internet: http://ww2.bgbm.org/ EuroPlusMed/ [accessed July 2018].

Jakucs, P. 1961: Die Phytozönologischen verhältnisse der flaumeichenbuschwälder südostmitteleuropas. Akademiai Kiadó, Budapest, pp. 244-250.

Janssen, J., Rodwell, J., García Criado, M., Gubbay, S., Haynes T., Nieto, A., Sanders, N., Landucci, F., Loidi, J., Ssymank, A., Tahvanainen, T., Valderrabano, M., Acosta, A., Aronsson, M., Arts, G., Attorre, F., Bergmeier, E., Bijlsma, R.-J., Bioret, F., Biță-Nicolae, C., I. Biurrun, Calix, M., Capelo, J., Čarni, A., M. Chytrý, Dengler, J., Dimopoulos, P., Essl, F., Gardfjell, H., Gigante, D., Giusso del Galdo, G., Hájek, M., Jansen, F., Jansen, J., Kapfer, J., Mickolajczak, A., Molina, J.A., Molnár, Z., Paternoster, D., Piernik, A., Poulin, B., Renaux, B., Schaminée, J.., Šumberová, K., Toivonen, H., Tonteri, T. Tsiripidis, I., Tzonev, R. \& Valachovič, M. 2016: European Red List of Habitats - Part 2. Terrestrial and freshwater habitats. Publications
Office of the European Union, Luxembourg, published on internet: https://forum.eionet.europa.eu/european-red-list-habitats/library/ terrestrial-habitats/f.-heathland-and-scrub/f3.1d-balkan-anatoliansubmontane-genistoid-scrub

Jordanov, D. (ed.). 1963-1979: Flora Reipublucae Popularis Bulgaricae. vol. 1-7. In Aedibus Acad. Sci. Bulgaricae, Serdicae [in Bulgarian].

Kožuharov, S. (ed.). 1992: Field Guide to the Vascular Plants in Bulgaria. Nauka \& Izkustvo, Sofia, 789 pp. [in Bulgarian].

Kožuharov, S. (ed.). 1995: Flora Reipublcae Bulgaricae. vol. 10. Editio Acad. "Prof. Marin Drinov", Serdicae, 428 pp. [in Bulgarian].

Kuzmanov, B. 1976: Genista L. - In: Jordanov, D. (ed.): Fl. Reipubl. Popularis Bulgaricae. Aedibus Acad. Sci. Bulgaricae, Serdicae, vol. 6, pp. 36-59. (in Bulgarian).

Mueller-Dombois, D. \& Ellenberg, H. 1974: Aims and methods of vegetation ecology. Wiley, London: $547 \mathrm{pp}$.

Ninov, N. 2002: Soils. In: Kopralev, I. (ed.): Geography of Bulgaria. ForKom, Sofia, pp. 277-315. [in Bulgarian].

Peev, D. (ed.). 2013: Flora Reipublcae Bulgaricae. vol. 11. Editio Acad. "Prof. Marin Drinov", Serdicae, 523 pp. [in Bulgarian].

Petrova, A. \& Vladimirov, V. (eds). 2009: Red list of Bulgarian vascular plants. Phytologia Balcanica 15(1): 63-94.

Petrova, A. \& Vladimirov, V. 2010: Balkan endemics in the Bulgarian flora. Phytologia Balcanica 16(2): 293-311.

Ponert, J. 1973: Neue taxonomisehe Kombinationen, Kategorien und Taxa vor allem der tiirkisehen Arten. Feddes Repertorium 83(9-10): 617-644

Raunkiaer, C. 1934: The life form of plants and statistical plant geography. Clarendon press, Oxford: $632 \mathrm{pp}$.

Stoyanov, S. 2014: Genista tetragona (Fabaceae), a neglected species in the Bulgarian flora. Phytologia Balcanica 20(2-3): 159-170.

The Plant List 2013: Version 1.1. Published on the Internet: http:// www.theplantlist.org/

Turrill, W. B. 1957: Genista lydia (Leguminosae). - Curtis's Bot. Mag. 156, n.s. tab. 292

Tzonev, R. 2002: Flora and vegetation of the Middle Danubian Plain between the valleys of Vit and Studena Rivers. PhD Thesis. Biol. Fak., Sofia Univ. St. Kliment Ohridski, Sofia [in Bulgarian, unpubl.].

Tzonev, R. \& Gussev, Ch. 2015: Mediterranean fields of Rumelian green weed (Genista rumelica) and Lydian green weed (Genista lydia). In: Biserkov, V., C. Gussev, V. Popov, G. Hibaum, V. Roussakova, I. Pandurski, Y. Uzunov, M. Dimitrov, R. Tzonev \& Tsoneva, S. (eds.): Red Data Book of the Republic of Bulgaria. vol. 3. Natural habitats. BAS-MOEW, Sofia, pp. 250-251.

Vasilev, P. 1983: Endemic plant communities in mountains of Bulgaria and their present state of conservation. In: International Symposium The Human-mountainous ecosystems relations. Vratza, pp. 84-90, [in Bulgarian].

Velenovský, J. 1890: Plantae novae bulgaricae II. Sitzungsberichte der Königl. Böhmischen Gesellschaft der Wissenschaften, mathem.naturwissensch. Classe, 1-3; 39-59.43. 
Velev, S. 2002: Climatic regionalisation. In: Kopralev,I. (ed.):

Geography of Bulgaria. ForKom, Sofia, pp. 155-156. [in Bulgarian].

Velčev, V. (ed.). 1982: Flora Reipublicae Popularis Bulgaricae. vol. 8. In Aedibus Acad. Sci. Bulgaricae, Serdicae, 518 pp. [in Bulgarian].

Velčev, V. \& Bondev, I. 1984a: Bulgarian and Balkan endemics in the vegetation cover of Bulgaria. In: Velčev, V. (ed.): Contemporary theoretical and applied aspects of plant ecology. BAS, Sofia, vol. 1, pp. 85-93. [in Bulgarian].

Velčev, V. \& Bondev, I. 1984b: Endangered and rare plant communities in Bulgaria. In: Velčev, V. (ed.): Contemporary theoretical and applied aspects of plant ecology. BAS, Sofia, vol. 1, pp. 94-105. [in Bulgarian].

\section{Appendix}

Checklist of the species from the floristic composition of the habitat F3.1d Balkan-Anatolian submontane genistoid scrub from Bulgaria (Note: The abbreviations in bold are explained under Figure 4 and 5).

\section{Equisetopsida}

Equisetaceae: Equisetum ramosissimum Desf. Bor,Cr,RRh

\section{Polypodiopsida}

Aspleniaceae: Asplenium adianthum-nigrum L.

Bor,H,RRh, Hypolepidaceae: Pteridium aquilinum (L.) Kuhn Kos,H,ERh,RRh

\section{Pinopsida}

Cupressaceae: Juniperus communis L. Bor,Ph,O, Juniperus deltoides R.P. Adams MSm,Ph,ERh,RRh

Pinaceae: Picea abies (L.) Karst. Bor,Ph,RRh, Pinus nigra Arnold ssp. pallasiana (Lamb.) Holmboe MSm,Ph,ERh,RRh, Pinus sylvestris L. Bor,Ph,RRh

\section{Magnoliopsida}

Aceraceae: Acer tataricum L. MSm,Ph,RRh, Anacardiaceae: Pistacia terebinthus L. PSp,Ph,RRh

Apiaceae: Anthriscus sylvestris (L.) Hoffm. Eur,H,RRh, Daucus carota L. Pal,Th,ERh,RRh, Daucus guttatus Sm. ssp. zahariadii Heywood BE,Th,ERh,RRh, Ferulago campestris (Besser) Grecescu Eur, H,RRh, Ferulago sylvatica (Besser) Rchb. MSm,H,O, Oenanthe pimpinelloides L. Eur,H,ERh, Orlaya daucoides (L.) Greuter MSm,Th,ERh,RRh, Orlaya grandiflora (L.) Hoffm. BSe,Th,O, Peucedanum arenarium Waldst. \& Kit. ssp. neumayeri (Vis.) Stoj. \& Stef. BSe,H,RRh, Pimpinella saxifraga L. Pal, H,RRh, Scandix pecten-veneris L. ssp. macrorhyncha (C.A.Mey.) Rouy \& E.G.Camus MSm,Th,Chz, Seseli pallasii Besser Eur,H,RRh, Seseli rigidum Waldst. \& Kit. ssp. rigidum $\mathbf{M S m}, \mathbf{H}, \mathbf{C h z}, \mathbf{R} \mathbf{R h}$,
Velčev, V. (ed). 1989: Flora Reipublicae Popularis Bulgaricae. vol. 9. In Aedibus Acad. Sci. Bulgaricae, Serdicae, 539 pp. [in Bulgarian].

Westhoff, V. \& van der Maarel, E. 1980: The Braun-Blanquet Approach. In: Whittaker, R. H. (ed.): Classification of Plant Communities. Junk, The Hague: pp. 289-399.

Zieliński, J., Tan, K. \& Tomaszewski, D. 2004: Notes on the taxonomy of Genista januensis and G. lydia (Fabaceae). Ann. Bot. Fennici 41: 453-457

Tordylium maximum L. MSm,Th,ERh, Torilis leptophylla (L.) Rchb. f. PSp,Th,ERh

Asclepiadaceae: Cionura erecta (L.) Griseb. MSm,Ph, ERh, Vincetoxicum hirundinaria Medik. ssp. hirundinaria

$\mathbf{P a l}, \mathbf{H}, \mathbf{C h z}$

Asteraceae: Achillea coarctata Poir. BSe,H,O, Achillea crithmifolia Waldst. \& Kit. BSe,H,O, Achillea millefolium L. Pal,H,O, Achillea pannonica Scheele Eur,H,Chz,RRh, Anthemis auriculata Boiss. BSe, Th,ERh, Anthemis cotula L. Pal,Th,RRh, Anthemis cretica L. MSm, H,Chz, Anthemis macedonica Boiss. \& Orph. ssp. macedonica BE,Th,RRh, Anthemis macedonica Boiss. \& Orph. ssp. orbelica (Pančić) Oberpr. BE,Th,RRh, Anthemis ruthenica M. Bieb. Pal,Th,RRh, Anthemis tenuiloba (DC.) R. Fern. BSe,H,RRh, Anthemis tinctoria L. Pal,H,O, Anthemis virescens Velen. BE,Th,ERh, Artemisia vulgaris L. Bor,H,RRh, Bellis perennis L. Pal,H,ERh, Carduus candicans Waldst. \& Kit. ssp. globifer (Velen.) Kazmi BSe,H,RRh, Carlina acanthifolia All. Eur,H,RRh, Carlina vulgaris L. Eur,Th,ERh, RRh, Carthamus lanatus L. MSm,Th,ERh, Centaurea cuneifolia Sm. BE,H,ERh,RRh, Centaurea diffusa Lam. PSp,Th, Chz, Centaurea rhenana Boreau ssp. rhenana $\mathbf{M S m}, \mathbf{H}, \mathbf{C h z}, \mathbf{R R h}$, Centaurea salonitana Vis. ssp. salonitana $\mathbf{P S p}, \mathbf{H}, \mathbf{R R h}$, Chondrilla juncea L. Pal,H,ERh, Cichorium inthybus L. Pal,H,O, Cirsium ligulare Boiss. MSm,H,RRh, Cirsium vulgare (Savi) Ten. Eur,H,RRh, Cnicus benedictus L. MSm,Th,ERh, Crepis sancta (L.) Babc. MSm, Th,ERh,RRh, Crepis setosa Haller f. Eur,Th,ERh,RRh, Crepis zacintha (L.) Babcock MSm,Th,ERh, Crupina vulgaris Cass. MSm,Th,O, Doronicum hungaricum Rchb. PSp,H,ERh,RRh, Echinops sphaerocephalus L. ssp. albidus (Boiss. \& Spruner) Kožuharov BSe,H,RRh, Erigeron acer L. Bor,Th,RRh, Erigeron annuus (L.) Pers. Bor, Th, RRh, Eryngium campestre L. PSp,H,O, Filago vulgaris Lam. Pal,Th,O, Hieracium bauhinii Besser Pal,H,O, Hieracium cymosum L. Pal,H,RRh, Hieracium hoppeanum Schult. Eur,H,O, Hieracium piloselloides Vill. ssp. piloselloides 
MSm,H,RRh, Hypochaeris glabra L. Eur,H,ERh,RRh, Hypochaeris radicata L. Eur,H,ERh,RRh, Inula hirta L. Pal,H,Chz, Inula oculus-christi L. Eur,H, Chz,RRh, Leontodon cichoraceus (Ten.) Sanguin. MSm,H,ERh, Leontodon crispus Vill. PSp,H,O, Leucanthemum vulgare Lam. Pal,H,RRh, Logfia arvensis (L.) Holub Eur,Th,O, Scorzonera hispanica L. MSm,H,RRh, Scorzonera laciniata L. MSm,H,ERh, Scorzonera mollis M. Bieb. MSm, H,RRh, Senecio vernalis Waldst. \& Kit. Eur, Th,ERh,RRh, Senecio vulgaris L. Pal,Th,ERh,RRh, Taraxacum officinale L. MSm, Th,ERh,RRh, Tragopogon dubius Scop. Eur,Th,ERh,RRh, Tussilago farfara L. $\mathbf{P a l}, \mathbf{H}, \mathbf{R R h}$, Xeranthemum annuum L. MSm, Th,O

Berberidaceae: Berberis vulgaris L. Eur,Ph,ERh

Boraginaceae: Anchusa officinalis L. PSp,H,RRh, Buglossoides arvensis (L.) I. M. Johnst. Pal,Th,O, Cynoglossum officinale L. PSp,H,ERh, Echium vulgare L. Pal,H,ERh,RRh, Myosotis arvensis (L.) Hill Pal,Th,ERh, Myosotis incrassata Guss. MSm, Th, RRh, Myosotis ramosissima Rochel MSmTh, ERh,RRh, Myosotis stricta Link ex Roem. \& Schult. Pal,Th,ERh,RRh, Onosma heterophylla Griseb. MSm,H,RRh

Brassicaceae: Alyssum alyssoides (L.) L. MSm,Th,Chz,RRh, Alyssum minutum Schltdl. ex DC. MSm, Th,ERh,RRh, Alyssum murale Waldst. \& Kit. MSmH,Chz,RRh, Arabidopsis thaliana (L.) Heynh. Bor,Th,ERh,RRh, Aurinia saxatilis (L.) Desv. Eur,H,Chz, Berteroa obliqua (Sm.) DC. MSm,H,ERh, Calepina irregularis (Asso) Thell. MSm,Th,ERh, Capsella bursa-pastoris (L.) Medicus Kos,Th,ERh, Capsella rubella Reut. MSm,Th,ERh, Cardamine hirsuta L. Pal,Th,ERh,RRh, Draba muralis L. Eur, Th,RRh, Erophila verna (L.) Chevall. ssp. verna Pal,Th,ERh,RRh, Erysimum diffusum Ehrh. Eur,Th, ERh, Rorippa thracica (Griseb.) Fritsch MSm,H,O, Teesdalia coronopifolia (J. P. Bergeret) Thell. MSm,Th, ERh,RRh, Thlaspi perfoliatum L. Eur,Th,ERh,RRh

Campanulaceae: Asyneuma anthericoides (Janka) Bornm. BE,H,RRh, Asyneuma limonifolium (L.) Janch.

BSe,H,ERh, Campanula cervicaria L. PSp,H,RRh, Campanula jordanovii Ančev \& Kovanda BE,H,Chz, Campanula lingulata Waldst. \& Kit. BSe,H,RRh, Campanula phrygia Jaub. \& Spach MSm,Th,ERh, Campanula rapunculus L. Pal,H,ERh,RRh, Campanula scutellata Griseb. BE,Th,RRh, Campanula sparsa Friv. BE,Th,RRh, Jasione heldreichii Boiss. \& Orph. Eur,H,ERh,RRh

Caryophyllaceae: Arenaria serpulifollia L. Pal,Th,O, Cerastium glomeratum Thuill. Kos, Th,ERh, Cerastium petricola Pančić BE,Th,RRh, Cerastium pumilum Curtis Eur,Th,O, Cerastium semidecandrum L. EurTh,ERh,RRh, Dianthus corymbosus Sibth. \& Sm. BE,H,ERh,RRh, Dianthus deltoides L. Eur,H,RRh, Dianthus giganteus d'Urv. ssp. giganteus MSm,H,Chz,RRh, Dianthus moesiacus Vis. \& Pančić ssp. moesiacus BE,H,RRh, Dianthus pallens $\mathrm{Sm}$. BSe,H,RRh,
Dianthus petraeus Waldst. \& Kit. BSe,H,Chz, Dianthus pinifolius Sm. ssp. pinifolius $\mathbf{B S e}, \mathbf{H}, \mathbf{O}$, Gypsophila muralis L. Pal,Th,ERh, Herniaria hirsuta L. Pal,Th,ERh, Holosteum umbellatum L. Pal,Th,ERh, RRh, Lychnis coronaria (L.) Desr. MSm,H,RRh, Minuartia hirsuta (M. Bieb.) Hand.-Mazz. ssp. falcata (Griseb.) Mattif MSm,H,Chz,RRh, Minuartia viscosa (Schreb.) Schinz \& Thell. Eur,Th,RRh, Moenchia erecta (L.) Gaertn., B. Meyer \& Scherb. MSm,Th,ERh, Moenchia mantica (L.) Bartl. Eur, Th,ERh,RRh, Petrorhagia illyrica (Ard.) P. W. Ball \& Heywood PSp,H,RRh, Petrorhagia prolifera (L.) P. W. Ball \& Heywood PSp,Th,O, Scleranthus dichotomus Schur MSmH,Chz,ERh, Scleranthus perennis L. Eur,H,O, Scleranthus verticillatus Tausch $\mathbf{M S m}, \mathbf{T h}, \mathbf{E R h}$, Silene armeria $\mathrm{L}$. Eur,Th,RRh, Silene bupleuroides Chater \& Walters PSp,H,RRh, Silene compacta Fisch. MSm,Th,ERh, Silene conica L. ssp. conica $\mathbf{M S m}, \mathbf{T h}, \mathbf{E R h}, \mathbf{R R h}$, Silene dichotoma Ehrh. Eur,Th,ERh, Silene flavescens Waldst. \& Kit. BSe,H,ERh, Silene frivaldszkyana Hampe BE,H,RRh, Silene gallica L. Kos, Th,ERh, Silene gallinyi Rchb. MSm, Th,ERh, Silene lerchenfeldiana Baumg. BSe,H,Chz,RRh, Silene otites (L.) Wibel Eur,H,ERh,RRh, Silene velenovskyana Jordanov \& Panov BE,H,RRh, Silene vulgaris (Moench) Garcke Pal,Th,RRh, Spergula pentandra L. MSm,Th,ERh,RRh, Stellaria graminea L. Pal, H,RRh, Stellaria media (L.) Vill. Kos, Th,RRh, Viscaria vulgaris Röhl. ssp. atropurpurea (Griseb.) Stoj Pal, H, Chz

Chenopodiaceae: Polycnemum arvense L. Pal,Th,RRh

Cistaceae: Cistus incanus L. MSm,Ph,ERh, Helianthemum nummularium (L.) Mill. MSm, H, Chz, RRh, Tuberaria guttata (L.) Fourr. MSm,Th,ERh

Convolvulaceae: Convolvulus arvensis L. Kos,H,ERh,RRh, Convolvulus cantabrica L. PSp, H,Chz, ERh,RRh

Corylaceae: Carpinus betulus L. Eur,Ph, Chz, Carpinus orientalis Mill. MSm,Ph,Chz,ERh, Corylus avellana L. Eur,Ph,RRh

Crassulaceae: Jovibarba heuffelii (Schott) A. \& D. Lőve BSe,H,RRh, Sedum acre L. Eur,H,ERh, RRh, Sedum album L. MSm,H,RRh, Sedum annuum L. Pal,Th,RRh, Sedum caespitosum (Cav.) DC. MSm,Th,RRh, Sedum grisebachii Boiss. \& Heldr. BE,H,RRh, Sedum hispanicum L. Eur,Th,Chz, RRh, Sedum maximum (L.) Suter Bor,H,RRh, Sedum ochroleucum Chaix MSm,H,Chz,RRh, Sedum rubens L. Eur,Th,ERh,RRh, Sedum stefčo Stef. BE,H,RRh, Sedum urvillei DC. Eur,H,Chz,RRh, Sempervivum leucanthum Pančić BE,H,RRh, Sempervivum erythraeum Velen. BE,H,Chz,RRh, Sempervivum marmoreum Griseb. $\mathrm{MSm}, \mathrm{H}, \mathrm{Chz}$

Cuscutaceae: Cuscuta approximata Bab. Hol,Th,ERh,RRh, Cuscuta campestris Yunck. Adv, Th, $\mathbf{O}$

Dipsacaceae: Knautia arvensis (L.) Coult. Pal,H,RRh, 
Scabiosa argentea L., BSe,H,ERh,RRh, Scabiosa columbaria L. Eur,H,RRh, Scabiosa triniifolia Friv. BE, $\mathbf{H}, \mathbf{O}$

Euphorbiaceae: Euphorbia cyparissias L. Eur,H,O, Euphorbia helioscopia L. Pal,Th,ERh, Euphorbia myrsinites L. MSm,H,O, Euphorbia niciciana Borbás ex Novák MSm,H,RRh, Euphorbia seguieriana Neck. Pal,H,ERh, Euphorbia taurinensis All. MSm,Th,ERh,RRh

Fabaceae: Astragalus depressus L. MSm,H,RRh, Astragalus onobrychis L. Pal,H,RRh, Chamaecytisus absinthioides (Janka) Kuzmanov BE,Ph,RRh, Chamaecytisus albus (Hack.) Rothm. Eur,Ph,ERh, Chamaecytisus austriacus (L.) Link Eur,Ph,RRh, Chamaecytisus calcareus (Velen.) Kuzmanov BE,Ch,Chz,RRh, Chamaecytisus jankae (Velen.) Rothm. BE,Ch,ERh, Chamaespartium sagittale (L.) Gibbs Eur,Ch,RRh, Coronilla varia L. Eur,H,RRh, Dorycnium herbaceum Vill. Eur,H, RRh, Genista carinalis Griseb. BSe,Ch,ERh,RRh, Genista lydia agg. $\mathbf{B S e}, \mathbf{C h}, \mathbf{O}$, Lathyrus pratensis L. Bor, H,RRh, Lathyrus sativus L. MSm,Th,RRh, Lathyrus sphaericus Retz., Pal,Th,Chz,RRh, Lembotropis nigricans (L.) Griseb. Eur,Ch,Chz, Lotus angustissimus L. MSm,Th.Chz,ERh, Lotus corniculatus L. Pal,H,ERh,RRh, Medicago lupulina L. Pal,Th,ERh,RRh, Medicago minima (L.) Bartal. Pal,Th,O, Medicago rigidula (L.) All. Eur,Th,O, Melilotus neapolitana Ten. MSm,Th,ERh, Melilotus officinalis (L.) Pall. $\mathbf{M S m}, \mathbf{T h}, \mathbf{C h z}$, Onobrychis caputgali (L.) Lam. MSm,Th,ERh Onobrychis gracilis Besser PSp,H,ERh,RRh, Ononis arvensis L. Pal,Ch,ERh,RRh, Ornithopus compressus L. MSm, Th,ERh, Trifolium alpestre L. ssp. alpestre $\mathbf{P a l}, \mathbf{H}, \mathbf{C h z}, \mathbf{R R h}$, Trifolium angustifolium L. MSm,Th,O, Trifolium arvense L. Pal,Th,O, Trifolium aureum Pollich. Pal, Th, RRh, Trifolium campestre Schreb Eur,Th,O, Trifolium cherleri L. MSm,Th,ERh,RRh, Trifolium dubium Sibth. Eur,Th,O, Trifolium glomeratum L. MSm,Th,ERh, Trifolium hirtum All. MSm,Th,O, Trifolium hybridum L. ssp. elegans (Savi) Asch. \& Graebn. Eur,H,ERh,RRh, Trifolium incarnatum L. ssp. molinerii (Hornem.) Syme MSm,Th,ERh, Trifolium medium L. ssp. balcanicum Velen.BE,H,RRh, Trifolium nigrescens Viv. PSp,Th,ERh,RRh, Trifolium pallidum Waldst. \& Kit. MSm,Th,ERh, Trifolium pannonicum Jacq. MSm,H,Chz,RRh, Trifolium purpureum Loisel. MSm,Th,ERh, Trifolium repens $\mathrm{L}$. Pal,H,ERh,RRh, Trifolium scabrum L. ssp. scabrum $\mathbf{M S m}, \mathbf{T h}, \mathbf{E R h}$, Trifolium setiferum Boiss. MSm,Th,ERh, Trifolium smyrnaeum Boiss. MSm, Th, RRh, Trifolium striatum L. ssp. striatum Eur,Th,ERh,RRh, Trifolium strictum L. Pal,Th,ERh,RRh, Trifolium subterraneum L. MSm,Th,ERh, Trifolium tenuifolium Ten. MSm,Th,ERh, Trifolium trichopterum Pancic BE,Th,RRh, Vicia angustifolia Grufberg Pal,Th,RRh, Vicia cordata Wulfen MSm,Th,ERh,RRh, Vicia cracca L. Pal,H, Chz,ERh,
Vicia grandiflora Scop. MSm, Th,RRh, Vicia hirsuta (L.) Gray Eur,Th,ERh,RRh, Vicia incana Gouan Eur,H,RRh, Vicia lathyroides L. Eur,Th,ERh,RRh, Vicia lutea L. MSm,Th,RRh, Vicia onobrychioides L. MSm,H,RRh, Vicia sativa L. Eur,Th,ERh,RRh, Vicia tetrasperma (L.) Schreb. Eur,Th,RRh, Vicia varia Host Eur,Th,ERh,RRh, Vicia villosa Roth Pal,Th,ERh,RRh

Fagaceae: Quercus dalechampii Ten. $\mathbf{M S m}, \mathbf{P h}, \mathbf{C h z}$, Quercus frainetto Ten. Eur,Ph,ERh Quercus pubescens Willd.

Eur,Ph,O

Fumariaceae: Fumaria rostellata Knaf Eur,Th,Chz,RRh

Gentianaceae: Centaurium erythraea Raf. ssp. austriacum

(Ronninger ex Fritsch) Kozuharov \& Petrova

MSm,Th,RRh, Gentiana cruciata L. Pal,H,RRh

Geraniaceae: Erodium ciconium (L.) L'Hér.

MSm,Th,ERh, Erodium cicutarium (L.) L'Hér. Bor,Th, ERh,RRh, Geranium columbinum L. MSm,Th,O, Geranium dissectum L. PalTh,ERh, Geranium molle L. Eur,Th,ERh,RRh, Geranium purpureum Vill. MSm,Th,ERh, Geranium rotundifolium L. Pal,Th,O, Geranium sanguineum L. Eur,H,RRh

Hypericaceae: Hypericum cerastoides (Spach) N. Robson BSe,H,O, Hypericum montbretii Spach $\mathbf{M S m}, \mathbf{H}, \mathbf{C h z}, \mathbf{R R h}$, Hypericum olympicum L. MSm,H,O, Hypericum perforatum L. Kos, H,O, Hypericum rumeliacum Boiss. BE,H,Chz,RRh

Lamiaceae: Acinos alpinus (L.) Moench BSeH,O, Acinos rotundifolius Pers. MSm,H,RRh, Acinos suaveolens ( $\mathrm{Sm}$.) Don MSm,H,Chz, Ajuga genevensis L. PSp,H,ERh,RRh, Clinopodium vulgare L. Bor,H,RRh, Lamium amplexicaule L. Pal,Th,ERh, Lamium garganicum L. MSm,H,Chz, Lamium purpureum L. Eur,Th,ERh,RRh, Lavandula angustifolia Mill. Adv,Ch,RRh, Mentha longifolia (L.) Huds. Pal,H,RRh, Nepeta nuda L. ssp. nuda Pal,H,RRh, Origanum vulgare L. ssp. vulgare Pal,H, RRh, Prunella laciniata (L.) L. Eur,H,O, Prunella vulgaris $\mathrm{L}$. Kos, H,ERh,RRh, Salvia verticillata L. MSm,H,RRh, Satureja pilosa Velen. BE,Ch,ERh, Stachys angustifolia M. Bieb. PSp,H,O, Stachys germanica L. ssp. germanica Eur,H,ERh,RRh, Stachys recta L. ssp. recta Eur,H,Chz,RRh, Teucrium chamaedrys L. MSm,H,ERh,RRh, Teucrium polium L. PSp,Ch,RRh, Thymus callieri Borbás ex Velen. ssp. urumovii Velen. BE,Ch,O, Thymus glabrescens Willd. Eur,Ch,ERh,RRh, Thymus longicaulis C. Presl MSm, Ch, O, Thymus sibthorpii Benth. BSe,Ch,ERh,RRh

Linaceae: Linum bienne Mill. MSm,Th,ERh,RRh, Linum catharticum L. Bor,Th,RRh, Linum trigynum L. MSm,Th,ERh,RRh

Oleaceae: Fraxinus ornus L. MSm,Ph, Chz, RRh, Jasminum fruticans $\mathrm{L}$. $\mathbf{M S m}, \mathbf{C h}, \mathbf{C h z}$, Syringa vulgaris $\mathrm{L}$. BSe,Ph,Chz,ERh

Papaveraceae: Papaver dubium L. MSm,Th,RRh, Papaver rhoeas L. Pal,Th,ERh 
Plantaginaceae: Plantago bellardii All. MSm,Th,ERh, Plantago coronopus L. Eur,Th,ERh,RRh, Plantago lanceolata L. Kos,H,ERh,RRh, Plantago media L. Bor,H,ERh,RRh, Plantago scabra Moench Pal,Th,ERh,RRh, Plantago subulata L. MSm,H,Chz,RRh

Plumbaginaceae: Armeria rumelica Boiss. BE,H,ERh,RRh Polygalaceae: Polygala major Jacq. Pal,H,Chz,RRh

Polygonaceae: Fallopia convolvulus (L.) Á.Löve Pal,Th,ERh, Polygonum rurivagum Jord. ex Boreau Bor,Th,RRh, Rumex acetosa L. Bor,H,ERh,RRh, Rumex acetosella L. Eur,H,O, Rumex pulcher L. Pal,H,ERh

Primulaceae: Anagallis arvensis L. Kos, Th, $\mathbf{O}$, Primula veris L. ssp. canescens (Opiz) Hayek ex Ludi Eur,H,RRh

Ranunculaceae: Clematis vitalba L. Eur,Ph,ERh,RRh, Ficaria verna Huds. ssp. calthifolia (Rchb.) Arcang. Eur,H,ERh,RRh, Nigella arvensis L. MSm,Th,ERh,RRh, Ranunculus gracilis E. D. Clarke MSm,H,ERh, Ranunculus illyricus L. Eur,H,O, Ranunculus millefoliatus Vahl MSm,H,ERh, Ranunculus polyanthemos L. Eur,H,RRh, Ranunculus rumelicus Griseb. MSm,H,O

Rhamnaceae: Paliurus spina-christi Mill. Pal,Ph,O

Rosaceae: Agrimonia eupatoria L. Eur,H,ERh,RRh, Amelanchier ovalis Medicus $\mathbf{P S p}, \mathbf{P h}, \mathbf{C h z}$, Aphanes arvensis L. Eur,Th,ERh,RRh, Cerasus avium (L.) Moench MSm,Ph,ERh,RRh, Cerasus mahaleb (L.) Mill. Eur,Ph,Chz, Crataegus monogyna Jacq. Bor,Ph,ERh,RRh, Filipendula vulgaris Moench Eur,H,Chz,ERh, Fragaria vesca L. Bor,H,RRh, Fragaria viridis Duchesne Pal,H,RRh, Malus dasyphylla Borkh. PSp,Ph,ERh, Potentilla argentea L. PSp,H,ERh.RRh, Potentilla detommasii Ten. MSm, H,RRh, Potentilla inclinata Vill. Pal,H,Chz, Potentilla laciniosa Waldst. \& Kit. ex Nestl. MSm,H,RRh, Potentilla neglecta Baumg. Bor,H,O, Potentilla pedata Willd. MSm,H,ERh,RRh, Potentilla recta L. Pal,H,O, Potentilla rupestris L. Bor,H,Chz, Prunus cerasifera Ehrh. ssp. cerasifera Pal,Ph,ERh,RRh, Prunus spinosa L. PSp,Ph,ERh,RRh, Pyrus pyraster Burgsd. MSm,Ph,ERh,RRh, Rosa agrestis Savi MSm,Ph,ERh, Rosa canina L. MSm,Ph,Chz,RRh, Rosa gallica L. Eur,Ph,ERh, RRh, Rosa myriacantha DC. ex Lam. \& DC. MSm,Ph,RRh, Rosa turcica Rouy MSm,Ph,ERh,RRh, Rubus canescens DC. Eur,Ph,ERh,RRh, Rubus thyrsanthus Focke Eur,Ph,Chz,ERh, Sanguisorba minor Scop. Bor,H,O Rubiaceae: Asperula purpurea (L.) Ehrend.

MSm,H,ERh,RRh, Asperula tenella Heuff. ex Degen $\mathbf{M S m}, \mathbf{H}, \mathbf{E R h}, \mathbf{R R h}$, Crucianella angustifolia L. MSm,Th,O, Cruciata laevipes Opiz Pal,H,RRh, Cruciata pedemontana (Bellardi) Ehrend. Pal,Th,ERh,RRh, Galium aparine L. Pal,Th,ERh,RRh, Galium divaricatum Pourr. ex Lam. MSm,Th,ERh,RRh, Galium flavescens Borbás BSe,H,Chz, Galium lovcense Urum. BSe,H,Chz, Galium lucidum All. MSm,H,ERh,RRh, Galium verum
L. Pal,H, O, Sherardia arvensis L. MSm,Th,ERh,RRh Santalaceae: Thesium arvense Horv. MSm,Th,ERh,RRh Saxifragaceae: Saxifraga graeca Boiss. BSe,H,ERh,RRh Scrophulariaceae: Digitalis lanata Ehrh. MSm,H,ERh, Digitalis viridiflora Lindl. BE,H,RRh, Euphrasia liburnica Wettst. BSe,Th,ERh,RRh, Euphrasia pectinata Ten. MSm,Th,O, Euphrasia picta Wimm. MSm,Th,ERh, Linaria genistifolia (L.) Mill. ssp. genistifolia PSp,H,O, Linaria pelisseriana (L.) Mill. MSmTh,ERh,RRh, Linaria simplex (Willd.) DC. MSm,Th,ERh, Odontites glutinosa (M. Bieb.) Benth. PSp,Th,RRh, Odontites lutea (L.) Clairv. Eur,Th,RRh, Odontites verna (Bellardi) Dumort. ssp. serotina (Dumort.) Corb. Eur, Th, RRh, Parentucellia latifolia (L.) Caruel MSm, Th,ERh, RRh, Rhinanthus rumelicus Velen. ssp. rumelicus BSe,Th, RRh, Verbascum densiflorum Bertol. MSm, H,RRh, Verbascum humile Janka BE, H,Chz, RRh, Verbascum lychnitis L. BSe,H,ERh,RRh, Verbascum speciosum Schrad. Eur,H,RRh, Veronica acinifolia L. MSm,Th,ERh, Veronica arvensis L. Pal, Th, Chz, RRh, Veronica jacquinii Baumg. ssp. jacquinii Eur, Ch,Chz, Veronica chamaedrys L. Pal,H,RRh, Veronica persica Poir. Pal,Th,ERh, Veronica praecox All. Eur,Th,ERh,RRh, Veronica verna L. Pal,Th,O

Ulmaceae: Ulmus minor Mill. Eur,Ph,ERh,RRh Valerianaceae: Valerianella carinata Loisel. Eur,Th,RRh, Valerianella coronata (L.) DC. Eur,Th, ERh,RRh, Valerianella dentata (L.) Poll. Eur,Th,ERh,RRh, Valerianella turgida (Steven) Betcke MSm,Th,ERh,RRh

Violaceae: Viola aetolica Boiss. \& Heldr. BE,H,RRh, Viola arvensis Murr. Eur,Th,ERh,RRh, Viola kitaibeliana Schult. Eur,Th,Chz, Viola tricolor L. ssp. tricolor Pal,Th,ERh,RRh

\section{Liliopsida}

Alliaceae: Allium flavum L. MSm,Cr,ERh,RRh, Allium guttatum (Steven) Regel PSp,Cr,RRh, Allium moschatum L. PSp,Cr,RRh, Allium oleraceum L. Eur,Cr,RRh, Allium paczoskianum Tuzson Bse,Cr, RRh, Allium rhodopaeum Velen. BE,Cr,RRh, Allium rotundum L. Pal,Cr,Chz,RRh Asparagaceae: Asparagus verticillatus L. PSp,Cr,RRh

Cyperaceae: Carex caryophyllea Latourr. Bor,H,RRh, Carex muricata L. Kos, H,ERh,RRh

Iridaceae: Crocus chrysanthus (Herbert) Herbert $\mathbf{B S e}, \mathbf{C r}, \mathbf{E R h}, \mathbf{R R h}$, Iris reichenbachii Heuff. BSe,Cr,Chz, Romulea linaresii Parl. ssp. graeca Bég. MSm,Cr,ERh

Juncaceae: Juncus bufonius L. Bor,Th, Chz, Luzula campestris ssp. campestris (L.) Lam. \& DC. Bor, H,ERh,RRh, Luzula forsteri (Sm.) DC. Bor,H,ERh

Liliaceae: Colchicum autumnale L. Eur,Cr,RRh, Gagea pratensis (Pers.) Dumort. Eur,Cr,RRh, Muscari comosum (L.) Mill. MSm,Cr,ERh,RRh, Muscari neglectum Guss. ex Ten. MSm,Cr,ERh, Muscari tenuiflorum Tausch PSp,Cr,O, Ornithogalum comosum L. MSm,Cr,ERh, 
Ornithogalum kochii Parl. Eur,Cr,O, Ornithogalum sibthorpii Greuter BSe,Cr,ERh, Ornithogalum sphaerocarpum A. Kern. MSm,Cr,ERh,RRh, Tulipa australis Link $\mathbf{M S m}, \mathbf{C r}, \mathbf{C h z}$

Orchidaceae: Orchis morio L. Eur,Cr,ERh, Orchis papilionacea L. MSm,Cr,RRh, Orchis purpurea Huds. MSm,Cr,ERh

Poaceae: Aegilops geniculata Roth MSm,Th,ERh, Aegilops lorentii Hochst. MSm, Th,ERh, Aegilops neglecta Req. ex Bertol. MSm,Th,ERh, Aegilops triuncialis L. Pal,Th,O, Agrostis capillaris L. Bor, H, Chz,RRh, Agrostis castellana Boiss. \& Reut. ssp. byzantina (Boiss.) Hack. ex Kneuck. MSm,H, ERh,RRh, Aira elegantissima Schur MSm,Th,ERh,RRh, Anthoxanthum odoratum L. Pal,H,O, Apera spica-venti (L.) P. Beauv. Bor,Th,ERh,RRh, Arrhenatherum elatius (L.) P.Beauv. ex J.Presl \& C.Presl. Pal,H,RRh, Avenula compressa (Heuff.) Sauer \& Chmel. BSe,H,O, Bellardiochloa violacea (Bellardi) Chiov. MSm,H,Chz,RRh, Brachypodium sylvaticum (Huds.) P. Beauv. Pal,H,ERh,RRh, Briza media L. Eur,H,ERh,RRh, Bromus mollis L. Bor,Th,O, Bromus racemosus L. Eur,Th,ERh, Bromus secalinus L. Bor,Th,ERh, Bromus squarrosus L. MSm,Th,O, Bromus tectorum L. Bor,Th, ERh,RRh, Chrysopogon gryllus (L.) Trin. PSp,H,O, Cleistogenes serotina (L.) Keng Eur,H,Chz,RRh, Cynosurus cristatus L. Eur,H,O, Cynosurus echinatus L MSm,Th,ERh,RRh, Dactylis glomerata L. Pal,H,O, Dasypyrum villosum (L.) Cand. MSm,Th,O, Dichanthium ischaemum (L.) Roberty Pal,H,O, Elymus hispidus (Opiz) Melderis ssp. hispidus PSp,H,RRh, Festuca dalmatica (Hack.) K. Richt. MSm, H,Chz,RRh, Festuca rupicola Heuff. BSe,H,RRh, Festuca valesiaca Schleich. ex Gaudin PSp,H,ERh, RRh, Holcus lanatus L. Eur,H,ERh,RRh, Koeleria macrantha (Ledeb.) Schult. Eur,H,RRh, Koeleria nitidula Velen. PSp,H,Chz,ERh, Lerchenfeldia flexuosa (L.) Schur ssp. flexuosa Bor,H,Chz, Lolium perenne L. Pal,H,ERh,RRh, Lolium rigidum Gaudin $\mathbf{M S m}, \mathbf{T h}, \mathbf{E R h}$, Melica ciliata L. Eur,H,ERh, RRh, Micropyrum tenellum Link MSm,Th,O, Milium vernale $\mathrm{M}$. Bieb. MSm,Th,ERh, Molineriella minuta (L.) Rouy MSm,Th,ERh, Phleum montanum C. Koch MSm,H,Chz,RRh, Phleum phleoides (L.) Karst. Pal,H,ERh, Phleum subulatum (Savi) Asch. \& Graebn. ssp. subulatum Pal,Th,ERh, Poa annua L. Kos,Th,ERh, Poa bulbosa L. Pal,Th,O, Poa compressa L. Eur,H,ERh,RRh, Poa trivialis L. Bor,H,ERh, Psilurus incurvus (Gouan) Schinz \& Thell. MSm,Th,Chz,RRh, Sesleria latifolia (Adamović) Degen BE,H,Chz, Stipa pulcherrima Koch PSp,H,RRh, Taeniatherum caputmedusae (L.) Nevski Pal,Th,ERh,RRh, Ventenata dubia (Leers) Coss. PSp,Th,ERh,RRh, Vulpia ciliata Dumort. MSm,Th,ERh, Vulpia myurus (L.) C. C. Gmel. Bor,Th,O 